\title{
Toward 'seeing' critically: a Bayesian analysis of the impacts of a critical pedagogy
}

\author{
Stella L. Ng ${ }^{1,2,8}$ (D) Jeff Crukley ${ }^{2,3} \cdot$ Ryan Brydges $^{4,6,8} \cdot$ Victoria Boyd $^{5,8}$. \\ Adam Gavarkovs $^{5,8}$ - Emilia Kangasjarvi ${ }^{6}$ - Sarah Wright ${ }^{7,8}$. \\ Kulamakan Kulasegaram $^{7,8} \cdot$ Farah Friesen $^{1} \cdot$ Nicole N. Woods ${ }^{7,8}$
}

Received: 16 May 2021 / Accepted: 14 November 2021 / Published online: 1 January 2022

(c) The Author(s) 2021

\begin{abstract}
Critical reflection supports enactment of the social roles of care, like collaboration and advocacy. We require evidence that links critical teaching approaches to future critically reflective practice. We thus asked: does a theory-informed approach to teaching critical reflection influence what learners talk about (i.e. topics of discussion) and how they talk (i.e. whether they talk in critically reflective ways) during subsequent learning experiences? Pre-clinical students $(n=75)$ were randomized into control and intervention conditions $(8$ groups each, of up to 5 interprofessional students). Participants completed an online Social Determinants of Health $(\mathrm{SDoH})$ module, followed by either: a SDoH discussion (control) or critically reflective dialogue (intervention). Participants then experienced a common learning session (homecare curriculum and debrief) as outcome assessment, and another similar session one-week later. Blinded coders coded transcripts for what (topics) was said and how (critically reflective or not). We constructed Bayesian regression models for the probability of meaning units (unique utterances) being coded as particular what codes and as critically reflective or not (how). Groups exposed to the intervention were more likely, in a subsequent learning experience, to talk in a critically reflective manner (how) (0.096 $[0.04,0.15]$ ) about similar content (no meaningful differences in what was said). This difference waned at one-week follow up. We showed experimentally that a particular critical pedagogical approach can make learners' subsequent talk, ways of seeing, more critically reflective even when talking about similar topics. This study offers the field important new options for studying historically challenging-to-evaluate impacts and supports theoretical assertions about the potential of critical pedagogies.
\end{abstract}

Keywords Critical reflection $\cdot$ Critical pedagogy $\cdot$ Equity $\cdot$ Bayesian $\cdot$ Social responsibility

Stella L. Ng

stella.ng@utoronto.ca

Extended author information available on the last page of the article 


\section{Introduction}

This paper analyzes the outcomes of one enactment of critical pedagogy, as an approach to teaching for critical reflection, which is a lens for critically reflective practice: a way of being and seeing in practice that orients the practitioner to question assumptions, power relations, and structures, and to change these when they are unhelpful ( $\mathrm{Ng}$ et al., 2019a, b). This article is important because these approaches to teaching (critical pedagogy) and to practice (critically reflective practice) may offer a way to address an important challenge in health professions education.

How can we prepare professionals to optimally perform the social roles of care? (Mykhalovskiy \& Farrell, 2005; Verma et al., 2005; Kumagai, 2014; Ng et al., 2020). These roles include the health advocate, communicator, collaborator, professional, and systems-based practitioner; collectively, they have been variably referred to as humanistic, intrinsic, or social roles (Dyne et al., 2002; Frank \& Danoff, 2007; Sherbino et al., 2011; Whitehead et al., 2014). Currently, dominant approaches to prepare practitioners for these social roles include teaching social determinants of health $(\mathrm{SDoH})$ and cultural competence, and using portfolios or similar 'reflective' documents. Each of these approaches have encountered considerable critique (Driessen et al., 2005; Kumagai \& Lypson, 2009; Metzl \& Hansen, 2014; Kuper et al., 2017; Ng et al., 2015a; Sharma et al., 2018).

Critiques include, for example, Sharma et al.'s (2018) discussion of how a SDoH approach can focus learners on race but not racism, poverty but not oppression, homosexuality but not homophobia. In essence, Sharma et al. contend that this focus risks perpetuating rather than transforming the inequities that a SDoH approach espouses to remedy, because it positions $\mathrm{SDoH}$ as aspects of individuals rather than consequences of society and systems, and thereby diverts focus onto changing individuals/patients instead of changing systems (Sharma et al., 2018). Approaches to cultural competence similarly risk discounting complex cultural experiences and identities and propagating a reductionist checkbox approach. This oversimplification and overgeneralization of individuality, complexities, and nuances can lead to rote performance of supposed cultural competence that can potentially do harm to patients (Kumagai \& Lypson, 2009). Self-reflective portfolios and related self-reflective assignments, which aim to inspire, document, and assess the development of social roles, can instead lead students to feel they must perform inauthentically and are being surveilled (Nelson \& Purkis, 2004; Hodges, 2015; Ng et al., 2015a, b; de la Croix \& Veen, 2018).

We propose that critical reflection can offer an alternative frame and rise to the challenges highlighted above. This frame and its associated teaching approach, critical pedagogy, are rooted in the critical scholarship of Habermas, Freire, hooks, contemporary education scholars such as Brookfield, Kemmis, and Kincheloe, and health professions education thinkers like Kinsella, Kumagai, and Wear (Habermas, 1971; Brookfield, 2000; Freire, 2000; Kemmis, 2005; Kinsella, 2006; Kumagai \& Lypson, 2009; Kumagai, 2014; Hooks, 2015; Ng et al., 2019a, b). Building from the concept of reflection-the active, persistent, and careful questioning of knowledge claims and their sources (Dewey, 1910) critical reflection focuses less on self and instead turns its gaze to personal and societal assumptions and unhelpful power relations, with the goal of improving how one practices one's chosen profession (Brookfield, 2000; Freire, 2000). A critically reflective professional adopts a critically reflective way of seeing and being that orients them to practice with a commitment to ethics and justice (Freire, 2000; Kumagai \& Lypson, 2009; Ng et al., $2015 \mathrm{a}, \mathrm{b})$. For example, professionals with a critically reflective way of seeing may not 
only understand disability but also notice and change subtle ableism embedded in a rehabilitation plan. They may not only understand how socioeconomic status influences health access but also recognize and aim to mitigate classism embedded in healthcare systems. Past research has demonstrated that critical reflection supports practice that is more compassionate (Rowland \& Kuper, 2018), collaborative (Ng et al., 2020), and equitable (Mykhalovskiy \& Farrell, 2005), thus providing an opportunity to prepare learners for the social roles of health care.

However, past research has also shown that professionals predominantly learn their critically reflective capabilities through their personal experiences and relationships (Mykhalovskiy \& Farrell, 2005; Rowland \& Kuper, 2018; Ng et al., 2020). For example, Rowland and Kuper (2018) found that physicians became more critically reflexive, and thus compassionate, after experiencing the patient role firsthand. $\mathrm{Ng}$ et al. (2020) found that professionals and patient caregivers attributed their own critically reflective views to personal relationships, past careers, and experiences occurring by happenstance, not to formal education. These forms of personal and experiential learning align with the principles of critical pedagogy, which emphasize learning through experience and engaged participation, and connecting with others' common humanity through sharing of stories (Kumagai et al., 2009; Halman et al., 2017; Baker et al., 2019, 2020). Nonetheless, the question remains: how to appropriately integrate critical reflection and pedagogy in more formal health professions education curricula.

Critical reflection scholars, working from social constructionist paradigms, have written about how to teach this way of seeing through critical pedagogy, and their contemporaries have evaluated applications of these approaches using qualitative research designs (Thille et al., 2018; Kumagai \& Lypson, 2009). However, in health professions education, an interdisciplinary field traditionally dominated by the biomedical model and experimentalist traditions, proponents of critical reflection and critical pedagogy often face questions of effectiveness. In particular, educators and researchers often expect to see measurable outcomes for educational interventions. However, the purpose of teaching critical reflection is not to enhance the acquisition of content knowledge or the performance of skills in a pre-determined manner; thus, its effects could be missed or misrepresented by traditional written (e.g. multiple-choice questions) and performance-based (e.g. station-based exams) measurements. Instead, we argue that teaching critical reflection influences students' views about, and capabilities for, practice-based learning and critically reflective practice when they experience indeterminate zones of practice - that is, uncertain, unique, value-conflicted, and dynamic aspects of practice (Schön, 1983; Cheng et al., 2017).

Thus, we propose that studying the teaching of critical reflection experimentally requires alternative approaches to measuring outcomes, in order to maintain paradigmatic compatibility (Tavares et al., 2020) with the origins of critical reflection, while also addressing questions posed by experimentalist models of health professions education. We aimed to fill this gap: to explore, experimentally, the theoretical assertion that teaching critical reflection as a capability can shift health professionals' ways of seeing in subsequent experiences. We conducted an experiment to address the questions: does teaching critical reflection influence what learners talk about (i.e. topic of discussion) and how they talk (i.e. whether they talk in critically reflective ways) during a subsequent learning session and debrief? Acknowledging that the passage of time can impact performance, we explored whether any effects changed one week after initial training. We used the way learners talked following a critically reflective dialogic teaching session as our experimental proxy for ways of seeing. This approach to analyzing talk/text to infer a way of seeing is aligned with how scholars have handled other value-laden constructs, such as professional 
identity (Kalet et al., 2018). Importantly, we did not judge the quality of the reflection but rather whether or not their talk was consistent with a definition of critical reflection that a critical pedagogical approach aimed to teach. We expected that teaching for critical reflection would not have an effect on the what of learners' talk-given critical reflection is less focused on content and more on framing (e.g. noticing not just age but ageism) - and expected it would impact how they see and thus talk about the same content (e.g. countering rather than adopting ageist language).

\section{Methods}

\section{Overview of study design}

The study was approved by and complied with the University of Toronto Office of Research Ethics and took place in Toronto, Canada. We developed a single teaching and learning session based on theories of critical reflection, reflexivity, and critical pedagogy, and on the teaching materials and scholarship of the first author and colleagues (Kinsella et al., 2012; Ng, 2012; Ng et al., 2015a, b; Phelan \& Ng, 2015; Halman et al., 2017; Baker et al., 2018, 2020; Ng et al., 2018, 2020). To test its effectiveness, we employed an established education research design meant to test the transfer of learning to subsequent/future experiences, rather than simply test immediate knowledge acquisition and retention, as outlined in Fig. 1.

This design intended to make visible how participants engage with, or see, a new learning experience following their instructional exposure to the critical pedagogical learning experience. Participants in the control and intervention conditions completed an online module about $\mathrm{SDoH}$, followed by different instructional exposures: either a critically reflective dialogue or further $\mathrm{SDoH}$ discussion. Then, participants in both conditions experienced two common learning sessions that served as our outcome assessment, one

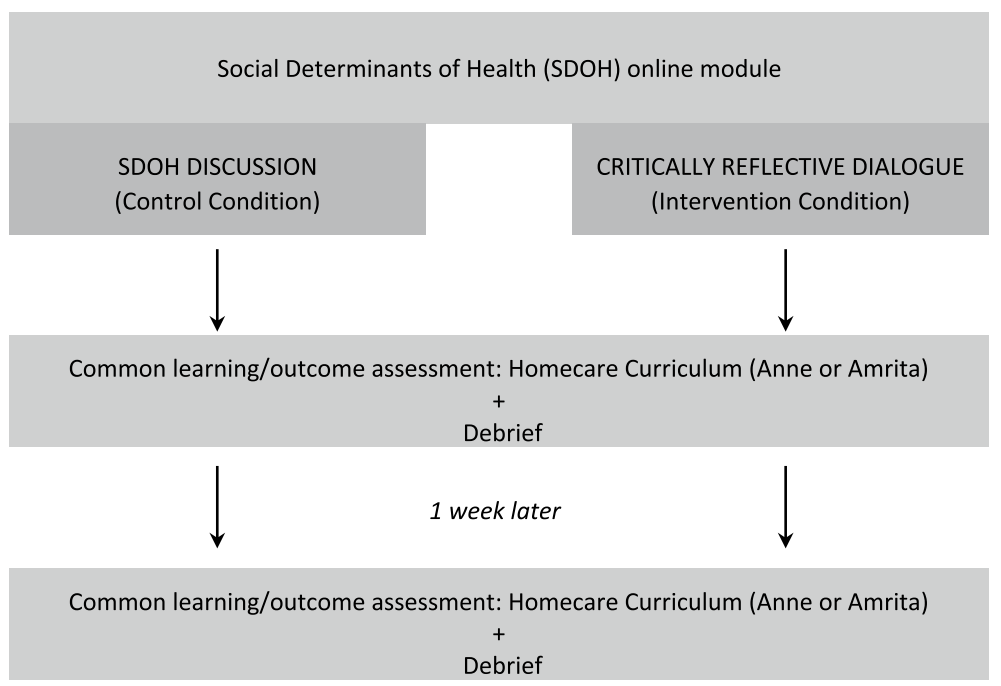

Fig. 1 Summary of research design (Mylopoulos \& Woods, 2014) 
immediately after the instructional exposure and another one-week after the initial training. These two common experiences enabled measurement of the outcomes of interest.

\section{Teaching materials}

The teaching materials used in this study are summarized in Table 1. They included an online module on SDoH (for both control and intervention conditions) and guides for the follow-up SDoH discussion (control) and for the critically reflective dialogue (intervention). An online homecare curriculum and a debriefing guide to follow the homecare curriculum served as the common learning resources that generated the outcome measures.

\section{Participants}

An interprofessional group of students $(n=75)$ were recruited from: the first two years of the University of Toronto MD program $(n=31)$, a fourth-year undergraduate pre-clinical service-learning course with students of mixed degree backgrounds $(n=18)$, the first year of master's level occupational therapy $(n=6)$, physical therapy $(n=6)$ and speech-language pathology $(n=10)$, and one student from dentistry, pharmacy, physiotherapy assistant, and radiation therapy programs $(n=4)$. We chose pre-clinical and early year students to minimize the amount of formal health professions education and clinical practice exposure they would have had.

Participants were assigned to sixteen groups of five, ensuring a multiprofessional complement of students per group to enable interprofessional learning. Eight groups were randomly assigned to the control condition and eight to the intervention condition. We began the study with 80 participants but five participants -2 from the control condition and 3 from the intervention condition-dropped out prior to participation due to factors external to the study (e.g. weather conditions).

\section{Procedures}

A research coordinator consented students and managed administrative elements of the data collection sessions. Both control and intervention participants completed a short $\mathrm{SDoH}$ curriculum online module. Each group of five participants completed this SDoH online module in a computer lab, each at their own pace using headphones for privacy, with a research coordinator present to ensure no distractions.

In their same groups of five, learning then diverged as participants proceeded to either a $\mathrm{SDoH}$ discussion (control) or critically reflective dialogue session (intervention). All sessions were completed in a small student lounge, with chairs set up in a circle, with the discussion/dialogue facilitator seated along with participants. These details align with a critical pedagogy approach in which the teacher-learner hierarchy is minimized and a learning climate conducive to openly challenging assumptions is emphasized. The SDoH session used a semi-structured facilitation guide ("Appendix 1"). A television screen was connected to a laptop to project supporting slides for the critical reflection session only (“Appendix 2"). Participants were provided with food and beverage during these sessions. Both the control and intervention conditions were one-hour in duration. Sessions were audio-recorded and later transcribed verbatim. The facilitators both held master's degrees and were trained to run their sessions by the first author. To minimize the confounding 


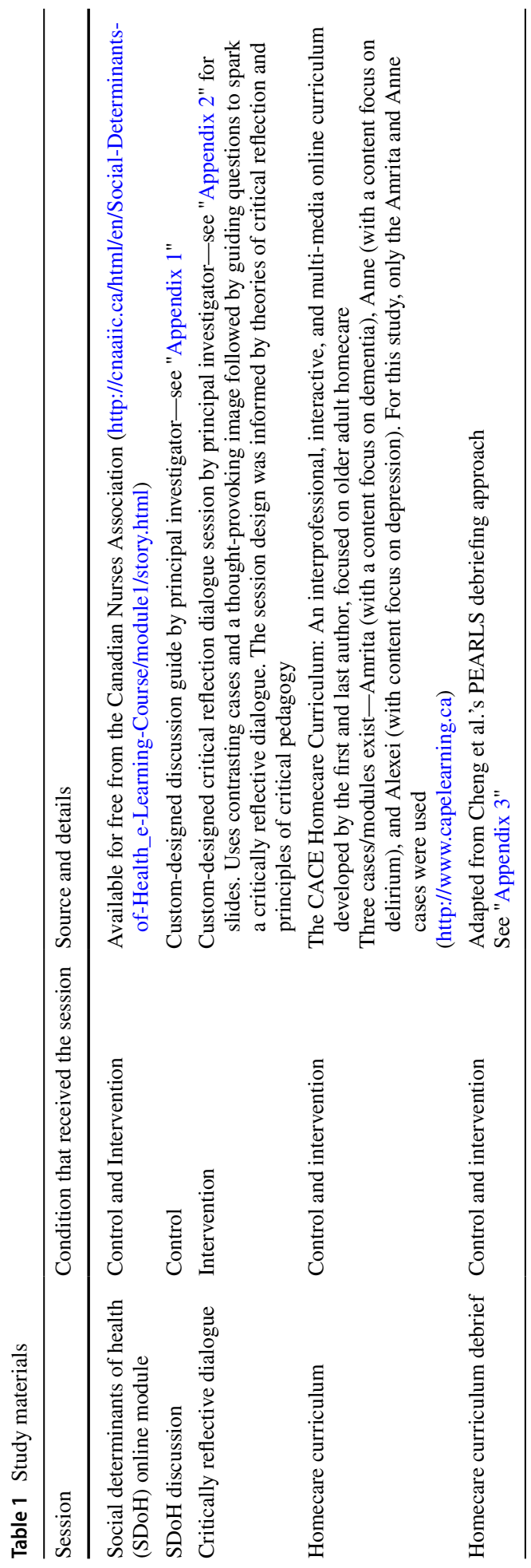


variable/factor of individual facilitation styles, the facilitators for the SDoH discussion and critically reflective dialogue session switched roles at the halfway point of data collection. We also included facilitator as a factor in the analysis to account for any potential effects.

After completing the SDoH discussion or critically reflective dialogue sessions, participants were given a brief 10-min break before reconvening within the same groups in a small conference room. The setup included a table for participants and facilitator, and television screen to display the learning resource, the CACE Homecare Curriculum (http:// www.capelearning.ca). A third facilitator ran the homecare curriculum and debriefs. Our aim was not to determine whether the participants learned about homecare or applied $\mathrm{SDoH}$ to the homecare context. Instead, we used the homecare curriculum followed by a debrief to uncover whether the critically reflective dialogue session, relative to the SDoH discussion, influenced what topics participants talked about during the curriculum and debrief, as well as how they talked during these experiences (in a critically reflective manner, or not). Participants were instructed to act as though they were directly involved in the patient case module. Each group completed one 35-min module from the curriculumeither "Amrita" (dementia-focused) or "Anne" (delirium-focused)—with the facilitator's guidance. The sessions were audio-recorded and transcribed verbatim.

The facilitator then guided a 30-min debriefing with participants, within their groups, immediately after completing the homecare curriculum. The facilitator was trained to use the Promoting Excellence and Reflective Learning in Simulation (PEARLS)-informed (Eppich \& Cheng, 2015) debriefing script (see "Appendix 3"). The debrief prompted participants to discuss their experience of the homecare curriculum, thoughts on the older adults' situations and needs, and key lessons learned. The debriefing was audio-recorded and transcribed verbatim. The homecare/debrief facilitator also held a master's degree, was trained by the first author, and remained blinded to each group's condition assignment.

One week later, participants were brought back in their groups to complete the followup homecare curriculum module plus debrief to determine if any effects identified in the previous session persisted or changed. All participants completed another patient case module (if they received the Amrita module, they now received Anne, and vice versa) followed by a similarly structured debrief ("Appendix 3"). The sessions and debriefs were audio-recorded and transcribed.

\section{Coding}

Analysis was performed on each group of five interprofessional learners' transcripts from the control (SDoH discussion) and intervention (critically reflective dialogue) sessions, as well as the homecare curriculum sessions and debriefs immediately post-instruction and at follow-up.

Before coding, meaning units were created, to ensure consistency in the amount and type of text to which what and how codes were subsequently applied, and that our two coders coded the same segments of text. Meaning units were created as follows. Within each transcript, every unique utterance by a participant (the boundaries of a unique utterance were determined by change in speaker) was labelled as a meaning unit, unless it met the exclusion criteria of: facilitator comments, neutral affirmations (mhmm, etc.), responses to homecare module quiz questions, responses about the quality of the module with no additional comment about content (e.g. "This module is fun"), responses to questions about participants' program/year, or clarifying questions (facilitator asks a question and 
participant asks for clarification, and statements that added no meaning). Every meaning unit was then ready to be coded with at least one what code and one how code.

To create the what coding framework, two researchers VB (co-author) and the first author, initially coded transcripts inductively to arrive at an agreed upon set of eight descriptive codes plus a "no code" code and associated descriptions for each code. They iteratively defined codes until they could be applied strictly to name the topic of meaning units, without further changes. While there were sub-codes used to assist the coding process, only the higher-level codes were used in our statistical analyses.

For the how coding framework, the following definition was used to code data as critically reflective, or not. Meaning units coded as critically reflective were statements that: move beyond a dominant discourse (e.g. discuss a social model as opposed to medical model of disability), question individual or societal assumptions/beliefs (e.g. a clinician's belief that they have authority over what a school does for a child with disability), demonstrate awareness of the broader system and how one is situated (e.g. recognize that personal support workers may lack resources and training opportunities relative to a regulated health professionals), question or challenge structures (e.g. question whether current funding approaches for homecare are limiting possible practices), and resist harmful practices (e.g. speak up if noticing something concerning) (Ng et al., 2019a, b). Meaning units coded as not critically reflective were: neutral descriptions, narrow views (e.g. illustrated through stigmatizing language), rote following/description of procedures or steps, blaming or patronizing the patient/caregiver/health worker.

Two blinded coders (VB, co-author and LN, acknowledged) were trained to apply these codes to the transcripts. We calculated the inter-rater agreement on eight transcripts to ensure the coders applied the codes consistently. For what codes, raw rater agreement was 95.9\%; for how codes it was $82.1 \%$. We determined that this was sufficient to allow the two coders to proceed independently, and subsequent transcripts were only coded by one coder each.

\section{Statistical analysis}

We conducted our analysis in accordance with the aims of this study: to investigate whether teaching for critical reflection influenced what students talked about during a future learning experience and how they talked about it. Thus, we constructed two regression models, one to model the presence of a what code in each meaning unit and one to model the presence of a how code in each meaning unit.

Paradigmatically aligned measurement and analyses were crucial to this study. We constructed, tested, and selected our models under a Bayesian framework. The following are our justifications. Frequentist inference addresses the question of how probable a set of observed data would be if there were no effect. We were specifically interested in addressing the question of how likely a code would be present in a meaning unit as a result of our intervention, which is an inherently Bayesian question. Bayesian inference directly quantifies uncertainty. It provides estimates of the probability of parameter estimates, their differences, and the uncertainty in those estimates and thus any conclusions drawn. Bayesian inference treats the gathered data as 'fixed' and models and their parameters as 'varying' attempts to explain the observed ('fixed') data, while quantifying the model and parameter 
uncertainty. Some in medical education have compared Bayesian statistics to constructivist grounded theory for the way in which it positions models as imperfect best attempts at representing the story of the data, with analyses informed by prior knowledge (Young et al., 2020). For details on Bayesian statistics, particularly details on the posterior distribution, we recommend McElreath (2020). All models were constructed using the Stan programming language (Carpenter et al., 2017) through the rstan (Stan Development Team, 2020) and brms (Burkner, 2017, 2018) packages in R statistical computing software (R Core Team, 2019).

We modelled predictive probabilities of what codes with a hierarchical multinomial regression model. Meaning units were categorized as containing any or all of nine codes, based on our inductive coding framework: Building on prior knowledge, CanMEDS roles, caregiver, professional expertise, patient, patient-psychosocial, recommendations for practice, social determinants of health, or no code for meaning units that remained in the codable set despite lacking relevance to any of the eight main codes. The definitions of these codes are included in the codebook within "Appendix 4". Population-level effects in this model included condition (control or intervention), session (initial instruction, initial homecare, initial debrief, follow-up homecare, follow-up debrief), and facilitator (Facilitator 1 or Facilitator 2). We also included interaction terms for: code*condition, code*session, condition*session, and facilitator*session. SDoH discussion group (for control participants) or critically reflective dialogue group (for intervention participants) was entered as a varying effect to adjust for clustering of meaning units within each five-member group. The presence of "no code," at the Instruction Session, in the Control Condition, with Facilitator One was used as the reference case. We used mildly informative priors on the regression coefficients: $\alpha_{\mathrm{i}} \sim \mathrm{N}(0,1), \beta_{\mathrm{i}} \sim \mathrm{N}(0,1), \sigma_{\mathrm{i}} \sim \operatorname{cauchy}\left(0, e^{1}\right)$.

We used Pareto smoothed importance sampling leave-one-out cross-validation (PSISLOO) (Vehtari et al., 2016) to evaluate and compare the fit of our full (hierarchical model) to an "empty" (intercept-only) model, and a non-hierarchical model (with the same population-level effects) to the data. We found our full model to be a significantly better fit to the data relative to both (i) the intercept-only model, with a favorable difference in PSIS-LOO expected log predictive density (ELPD) of 1599.8 (with a standard error of 42.2), and (ii) the non-hierarchical model with an ELPD of 93.9 (with a standard error of 13.3).

To model the predictive probabilities of the how codes, we constructed a hierarchical binary logistic regression model. Meaning units were categorized binomially as either present or absent of critical reflection. Population-level effects in this model included condition (control or intervention), session (instruction, initial homecare, initial debrief, followup homecare, follow-up debrief), and facilitator (Facilitator 1 or Facilitator 2). We also included interaction terms for: condition*session and facilitator*session. As in the what model, SDoH discussion group (for control participants) or critically reflective dialogue group (for intervention participants) was entered as a varying effect to adjust for clustering of meaning units within five-member groups. The Instruction Session, in the Control condition, with Facilitator One, was used as the reference case. We used mildly informative priors on the regression coefficients: $\alpha_{\mathrm{i}} \sim \mathrm{N}(0,1), \beta_{\mathrm{i}} \sim \mathrm{N}(0,1), \sigma_{\mathrm{i}} \sim$ cauchy $\left(0, e^{1}\right)$.

As conducted with our what model, we used PSIS-LOO to evaluate and compare the fit of our full (hierarchical model) to an "empty" (intercept-only) model, and a non-hierarchical model (with the same population-level effects) to the data. We found our full model to be a significantly better fit to the data relative to both (i) the intercept-only model with a 
favorable difference in PSIS-LOO ELPD of 172.6 (with a standard error of 15.5), and (ii) the nonhierarchical model with an ELPD of 18.0 (with a standard error of 6.1).

To evaluate the effect of our intervention, we calculated the distribution of differences in posterior predicted probabilities of codes being present in each Session Type and then determined if the $89 \%$ highest density credible intervals of these predicted difference distributions included zero where the inclusion of zero was taken as an indication of no difference between Conditions. The credible interval is the range of the posterior distribution containing the specified proportion (i.e. 89\%) of the parameters of interest (i.e., the differences in posterior predicted probabilities) such that one could say: "given the observed data, the effect has an $89 \%$ chance of falling in this range" as opposed to a less intuitive frequentist confidence interval, which would be interpretable as "there is an $89 \%$ probability that when computing a confidence interval from data of this sort, the effect falls within this range" (Makowski et al., 2019). The $89 \%$ credible interval is recommended by a number of leading Bayesian statistics thinkers for its computational stability relative to $95 \%$ intervals (Kruschke, 2014). While $90 \%$ was also proposed for this same reason, McElreath $(2014,2020)$ suggested that $89 \%$ makes potentially more sense because 89 is "the highest prime number that does not exceed the already unstable $95 \%$ threshold."(Makowski et al., 2019a, b). Because Bayesian analyses yield probability distributions of parameter values (e.g., regression coefficients) calculated directly from observed data, they do not require calculation of $p$ values or their associated confidence intervals. Rather, uncertainty is quantified directly from the calculated probability distributions of parameters (Kruschke \& Liddell, 2018).

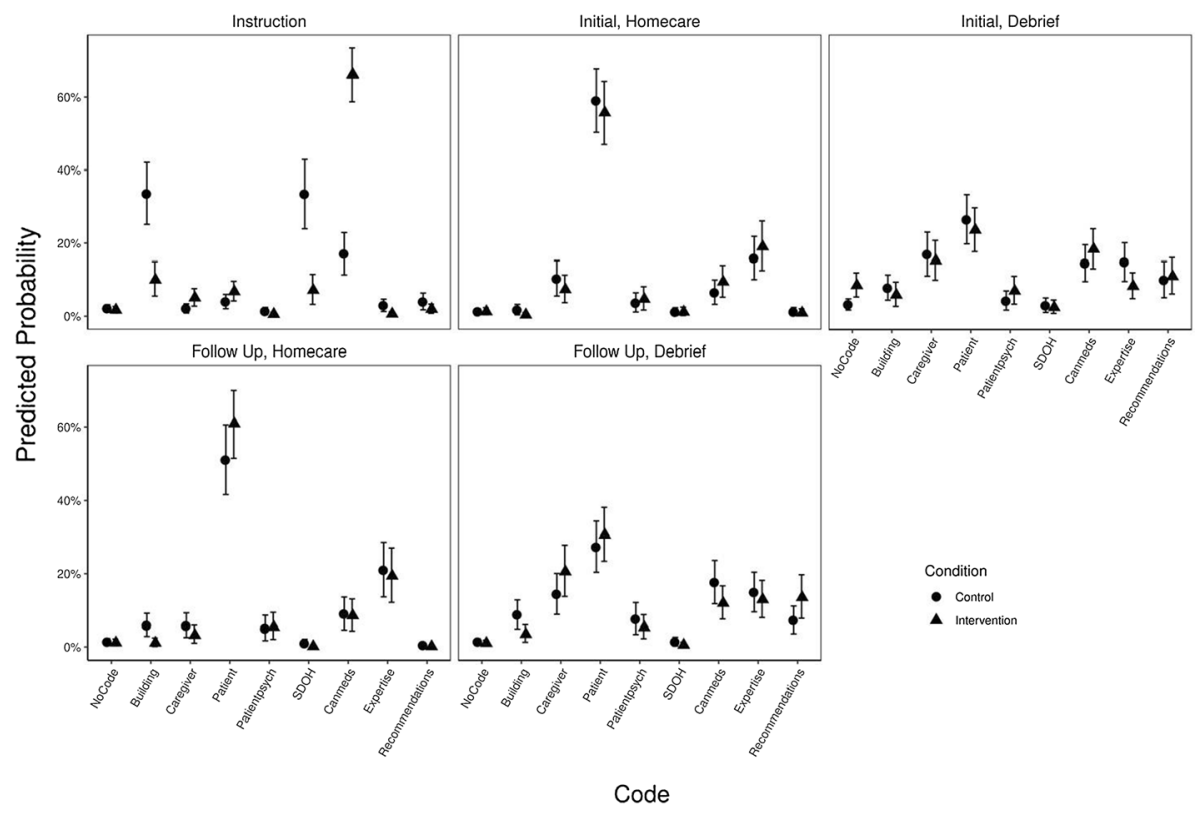

Fig. 2 Mean predictive probabilities by session type and condition for "what" codes 


\section{Results}

\section{What learners talked about}

A summary of our final hierarchical model for what codes is presented in Fig. 2 and a regression summary table of our "empty" (intercept-only) model, a non-hierarchical model, and our final hierarchical model for what codes is included in "Appendix 5".

Figure 2 shows mean posterior predicted probabilities together with the respective $89 \%$ highest density credible intervals of what codes by session type and condition.

We see a higher probability of "CanMeds" being coded for meaning units deriving from the critically reflective dialogue instruction sessions $(0.64[0.57,0.71])$ than the SDoH instruction sessions $(0.17$ [0.11, 0.23]), and a higher probability of "building on prior knowledge" and "SDoH" being coded during the SDoH instruction sessions $(0.33$ [0.24, $0.44]$ and $0.35[0.24,0.46]$, respectively) than in the critically reflective dialogue instruction sessions $(0.1[0.06,0.15]$ and 0.07 [0.03, 0.11], respectively). Otherwise, the probabilities of codes being applied to a meaning unit were virtually equivalent between conditions for our what codes.

Figure 3 depicts the posterior predictive difference distributions for each code in each Session Type between SDoH and critically reflective dialogue groups. Points represent mean probability differences; bars represent the $89 \%$ highest density credible interval surrounding the means; shaded regions indicate the distribution of posterior probability differences, and the dashed lined marks zero.

As depicted in Fig. 3, the probability of "building on prior knowledge" and "SDoH" being coded were more likely for the SDoH instruction sessions than in the critically reflective dialogue instruction sessions (differences 0.24 [0.31, 0.16] and 0.26 [0.33, 0.2], respectively). The probability of "CanMeds" being coded was more likely in the critically reflective dialogue instruction sessions than in the $\mathrm{SDoH}$ instruction sessions (difference of $0.49[0.43,0.55])$.

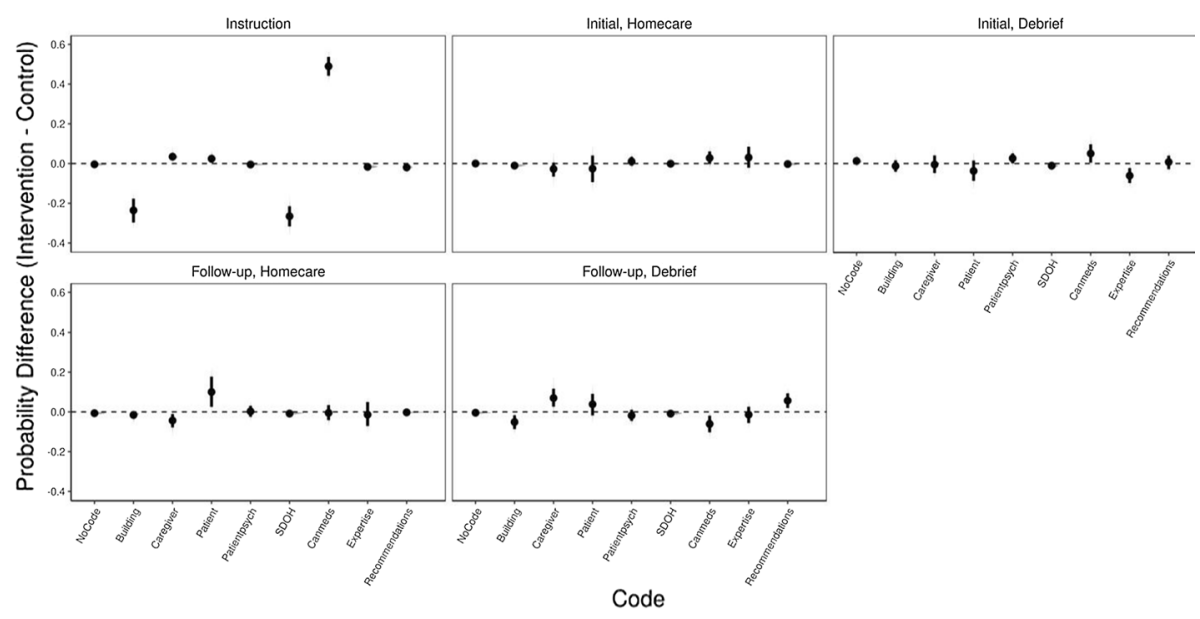

Fig. 3 Posterior predicted difference distributions by session type for "what" codes 


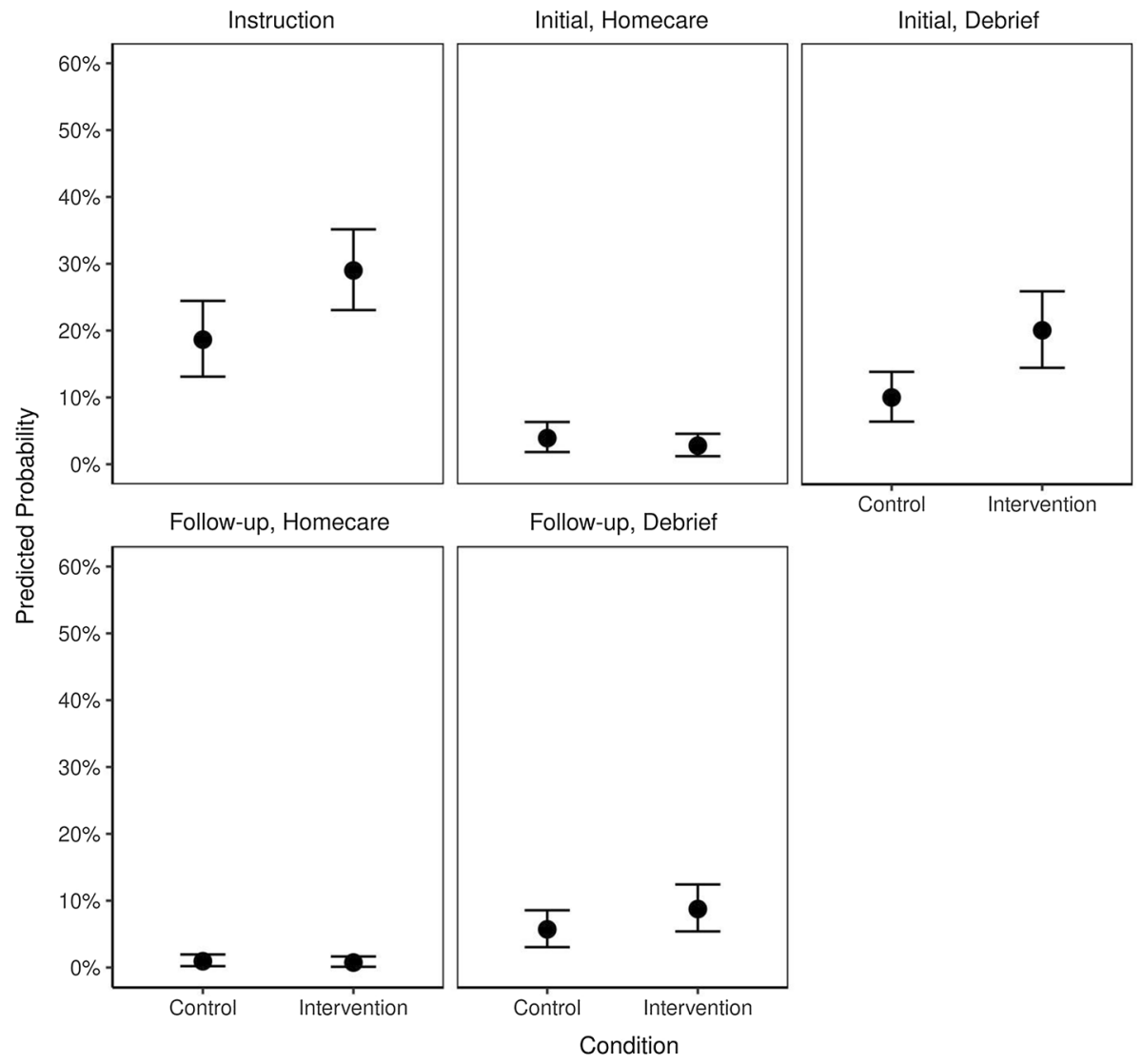

Fig. 4 Mean predictive probabilities for meaning units coded as critically reflective by session type and condition

Overall, these results show that during the common learning conditions (i.e. both initial and follow-up) serving as our outcome assessment, no what codes were more, or less, probable among meaning units deriving from the intervention versus control conditions.

\section{How learners talked}

A summary of the final model for how participants spoke (critically reflective or not) is presented in Fig. 4. The regression summary table of our "empty" (intercept-only) model, a non-hierarchical model, and our final hierarchical model for how codes is included in "Appendix 5".

Overall, there was a $10 \%$ difference between the probability of a meaning unit being coded as "critically reflective" between control and intervention conditions at initial debrief, though the probability of any meaning unit being coded as such was low across all sessions (instruction, initial and followup homecare and debrief) (Table 2). 
Table 2 Probabilities of critically reflective codes per meaning unit within condition and session type

\begin{tabular}{lll}
\hline Condition & Session type & Estimate [89\% CI] \\
\hline Control & Instruction & $0.18[0.12,0.25]$ \\
Control & Initial, Homecare & $0.04[0.01,0.07]$ \\
Control & Initial, Debrief & $0.1[0.06,0.15]$ \\
Control & Follow Up, Homecare & $0.01[0,0.02]$ \\
Control & Follow Up, Debrief & $0.06[0.03,0.09]$ \\
Intervention & Instruction & $0.3[0.24,0.37]$ \\
Intervention & Initial, Homecare & $0.03[0.01,0.05]$ \\
Intervention & Initial, Debrief & $0.2[0.13,0.27]$ \\
Intervention & Follow Up, Homecare & $0.01[0,0.02]$ \\
Intervention & Follow Up, Debrief & $0.09[0.05,0.13]$ \\
\hline
\end{tabular}

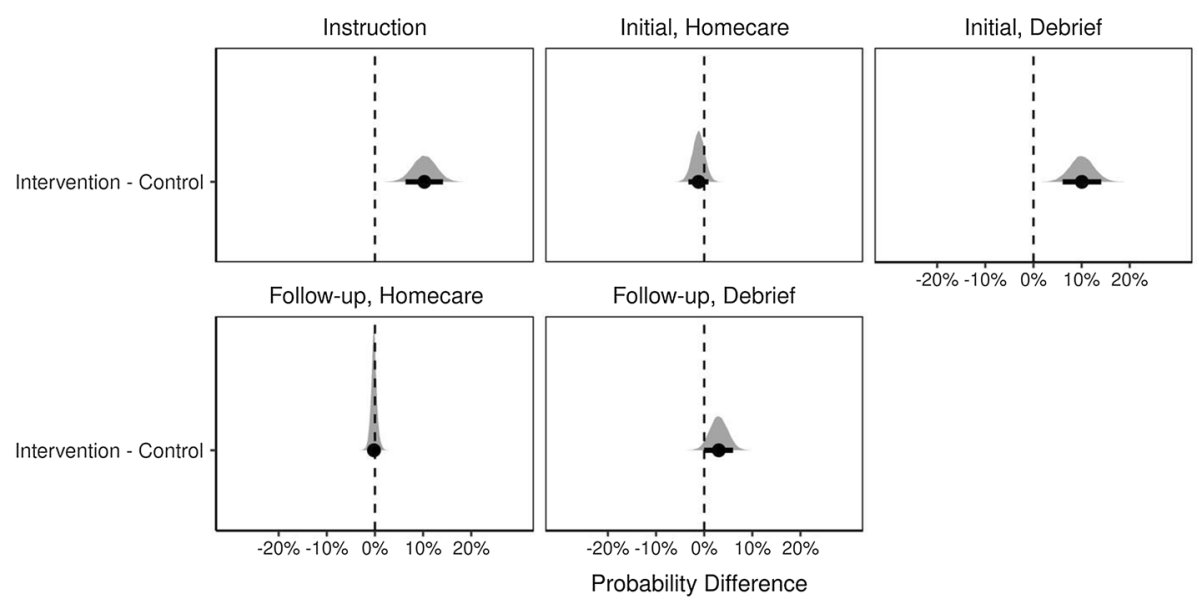

Fig. 5 Posterior predictive difference distributions for meaning units coded as critically reflective by session type

Figure 5 depicts the posterior predictive difference distributions for meaning units being coded as critically reflective in each Session Type between SDoH and critically reflective dialogue groups. Points represent mean probability differences; bars represent the $89 \%$ highest density credible interval surrounding the means; shaded regions indicate the distribution of posterior probability differences, and the dashed lined marks zero.

The probability of a meaning unit being coded as "critically reflective" was higher for the intervention condition at instruction $(0.112[0.05,0.17])$ and initial debrief $(0.096[0.04,0.15])$.

\section{Discussion}

We asked whether a critically reflective dialogue session would impact what learners talked about and how they talked. Answering this question, experimentally, is important to conversations about teaching for the social aspects of healthcare. As anticipated, while 
the instructional conditions focused on different content, the probability of specific content being discussed during the homecare and debrief outcome measurement was similar between participants exposed to the intervention versus control condition. By contrast, and as hypothesized, we did observe an impact on how participants spoke, with those exposed to the critically reflective dialogue sessions tending to speak in more critically reflective ways in their subsequent learning experience. This impact was seen even though learners moved to a novel context/content area for the future learning activity (from a pediatric context to an older adult context). This impact during the initial common learning session did not persist well over time, as the difference in probability was markedly reduced at the oneweek follow up session. Overall, this study showed that we could demonstrate the impact of teaching for critical reflection on learners' subsequent ways of seeing, utilizing novel and paradigmatically congruent analysis methods; albeit the observed probability differences between conditions were small.

\section{Interpreting the results and outcomes}

In terms of what learners talked about, it makes sense that the control instruction session led to more talk about SDoH and the intervention instruction session to more talk about CanMEDS. The SDoH session specifically asked learners to reflect on SDoH. The critical reflection sessions did not explicitly focus on CanMEDS; however, critical reflection affords a focus on these roles. The cases used to spark dialogue during the critical reflection sessions focused on issues that would invoke contemplation about approaches to collaboration, advocacy, and professionalism. Beyond initial instruction, however, there was no effect of condition on what learners talked about during their future homecare curriculum or debrief. This finding suggests that teaching critical reflection in the dialogic manner we used neither adds to nor detracts from learners' topical content focus as they move forward in their learning.

Of most interest to us is how learners talked-specifically, our finding that the learners exposed to critically reflective dialogue went on to produce more critically reflective meaning units during their future learning - when debriefed about their homecare curriculum experience. While the difference in probability between control and intervention groups is low at first glance (10\%), we interpret this difference as meaningful. Overall, we would expect the potential for any utterance to be critically reflective, during the homecare curriculum and debrief, to be low for two reasons. First, the intervention produced minimal exposure to critical pedagogy and second, over the course of the homecare curriculum and debrief participants would make many descriptive statements that would by nature have low potential or need to be critically reflective. Indeed, the probability for a meaning unit to be critically reflective even in the intervention condition was only $20 \%$, which is low and expected for the aforementioned reasons. Thus, a small difference is meaningful to this initial experimental study that explores the outcomes of teaching for critical reflection. Credible intervals and the degree of belief, in the form of uncertainty estimates, are generally the focus of Bayesian approaches rather than the point estimates and binary decisions (i.e. reject the null) used in frequentist approaches. In our study, our measure of central tendency (median estimates) of differences was close to zero with narrow credible intervals in almost all what codes. Of import to our main research question, for our how codes, zero was not a probable estimate. We can be confident in our conclusions because the models indicated the data moved the posterior distributions away from the priors. Taken 
together, this information indicates sufficient data from which to draw meaningful inference (Kruschke \& Liddell, 2018; McElreath, 2020).

As in all studies, our interpretations must be constrained according to our design and its limitations. Our sample size was relatively small and heterogenous, although all were university students intending to practice as health professionals in the future. In aiming to balance paradigmatic alignment (Creswell, 2003; Baker et al., 2020; Tavares et al., 2020) with experimental design principles, we may have imposed some limitations on our experimental approach. One such design choice was our group-level focus. Our learning conditions occurred in groups and our analyses did not code utterances per individual. We justified this because we wanted to elicit conversations in an interprofessional group learning / simulated practice situation, during which students were unaware that we would be coding their talk for critical reflection; we expected this would prevent them from performing to our measure. A study by Thille et al. (2018) evaluating a dialogic approach to foster critical reflexivity also analyzed group conversations, preserving group dynamics purposefully. Likewise, our group debriefs enabled us to obtain an aligned and authentic sense of learners' ways of seeing as they talked amongst their groups. However, while these choices were paradigmatically justified for critical reflection and pedagogy, our focus on the group as a dialogic unit meant that we were unable to see whether individual learners consistently enacted critically reflective ways of seeing.

While many scholars-including some on our author team-have argued that assessing reflection is fraught (Sumsion \& Fleet, 1996; Hodges, 2015; Ng et al., 2015a), this study makes an important contribution by demonstrating that two raters can reliably code whether a statement is critically reflective or not. This study was about outcome of teaching, not about assessment of individuals. We looked at presence or absence of critical reflection to determine whether a teaching approach had its intended effect; we did not assess the quality of critical reflection. We continue to caution strongly against judging the quality of an individual's reflective thought; as others note, doing so can take on a tone of surveilling learners' personal and political beliefs (Nelson \& Purkis, 2004; Hodges, 2015). Further, assessing reflection may take away from its authenticity, making it overly prescriptive (Hodges, 2015; Ng et al., 2015a; de la Croix \& Veen, 2018). Arguably, critical reflection is more readily identifiable and assessable than other forms of reflection because the critical lens derives from a body of critical theory ( $\mathrm{Ng}$ et al., 2019b). Thus, the forms of knowledge one would expect to observe are pre-defined and can be identified. That said, we still argue that assessing the quality of critical reflection as opposed to its presence may be problematic for both psychometric reasons and reasons of paradigmatic misalignment (Sumsion \& Fleet, 1996; Koole et al., 2011; Moniz et al., 2015; Ng et al., 2015a, b; Grierson et al., 2020).

\section{Educational design}

When interpreting our main findings, it is important to draw attention to three main elements of educational design. First, our pedagogical approach to the critically reflective session was carefully and deeply informed by theories of how to foster critical reflection $(\mathrm{Ng}$, 2012, Ng et al., 2015a, 2019a). Rather than teaching learners theory about critical reflection, these sessions aimed to equip them to disrupt dominant assumptions, to address the power differentials in the room, to ask questions rather than aim to identify solutions, and to envision ways forward beyond the status quo. They experienced real case examples from past practice-based research (Ng et al., 2015b; Phelan \& Ng, 2015). 
Second, the learning environment setup was purposeful and aligned with critical pedagogical principles (Greene, 1986; Hooks, 1994; Freire, 2000; Halman et al., 2017;). Facilitators sat in a circle with participants to reduce the sense of a facilitator-participant power differential, the presence of food was intended to foster comfort and informality, the spaces and lighting were chosen to help construct an environment conducive to dialogue. These features of the "instruction" would be considered important for fostering dialogue as they promote comfort and connection amongst learners and the facilitator. These environmental features were the same for both the control and intervention conditions; future research could explore the influence of such factors in learning. We believed that attending to these features may be important to overcome the challenges in setting up critical pedagogies against a dominant backdrop of objectivity and certainty in the health professions (Kuper et al., 2017; Ng et al., 2019a, b; Whitehead et al., 2011) but this belief would need to be explored in future studies. Along these lines, calling the critically reflective dialogue session "instruction" demonstrates the dominance of objectivist paradigms and is incongruent with principles of critical pedagogy. Notably, we use "instruction" to be consistent with our education research design; however in critical pedagogy, there is less of an emphasis on a single instructor or instruction per se, as learners bring their own valid experiences and knowledge worth sharing, to the table, alongside the facilitator's experience and knowledge (Hooks, 1994; Freire, 2000; Halman et al., 2017).

Third, we allotted a limited amount of time/exposure to critically reflective learning, for study feasibility and to represent the reality in health professions education. Many lament this "tacking on" or "squeezing in" of one-off, brief educational experiences deriving from alternative traditions (Ousager \& Johannessen, 2010; Diachun et al., 2014; Charise, 2017). Indeed to see the effect of critical pedagogy persist over time, critical approaches to education would need to be embedded more consistently, comprehensively, and longitudinally in a training program ( $\mathrm{Ng}$ et al., 2020). A potential consequence of this increased intensity could be an increased probability of learners' utterances being critically reflective.

One promising approach to bridge critical pedagogy with cognitivist education paradigms (which emphasizes knowledge acquisition as opposed to ways of seeing and being [Baker et al., 2020]) may lie in our debriefing script based on Cheng's PEARLS framework (Eppich \& Cheng, 2015). That there was no effect of condition on how learners talked during the homecare curriculum itself was unsurprising as it was a structured curriculum. But during the debrief, in which more open and critical reflection prompting questions were posed, the intervention did have its expected effect. Questions like "what were your thoughts about the family caregiver" could in and of themselves trigger critical reflection. For example, this question may trigger insights or queries about whether the health and social care systems adequately support such caregivers. The difference between learners who were exposed to the intervention versus those who were not suggests that the intervention supports learners to take greater advantage of such debriefing prompts. It is possible that the PEARLS approach to debriefing is a form of continued critical reflection teaching. However, the reduced impact at the oneweek follow up debrief suggests that continued debriefing alone is insufficient to sustain the effects of the critical reflection teaching. Future research could delve more deeply into the most effective way to sustain critical reflection throughout and beyond formal health professions training.

Ultimately, we believe this study offers a much-needed bridge between critical pedagogy aiming to foster critical reflection, and experimentalist approaches to studying educational interventions. In the interdisciplinary field of health professions education, paradigmatic diversity offers challenges and opportunities (Young et al., 2020). We sought to reconcile a difference that caused much collegial debate amongst members of our interdisciplinary team. 
Experimentalists argued that claims about the effects of teaching for critical reflection were under-substantiated given a paucity of experimental evidence. The critical pedagogues argued that such forms of evidence would relegate authentic, embodied reflective capabilities to inauthentic and overly prescriptive caricatures. Through interdisciplinary debate and dialogue, our team developed an approach to advancing knowledge on the teaching of critical reflection that satisfied both perspectives. What the field does with this bridge remains to be seen; it may be prudent to proceed with commitment to criticality and dialogue as both our research reported in this article, and the pedagogy within it, demonstrated.

\section{Appendix 1: SDoH discussion guide}

- What did you think of that learning module?

- Did anything surprise you?

- Did anything seem confusing to you?

- Have you had personal experiences in which the social determinants of health have influenced:

- Your well-being

- The well-being of a close friend or family member?

- How did you feel?

- How did you handle this?

- Would you do things differently in the future?

- As a future health professional, what will you do to help address the social determinants of health?

- Do you have anything else to add?

\section{Appendix 2: Critically reflective dialogue session slides}

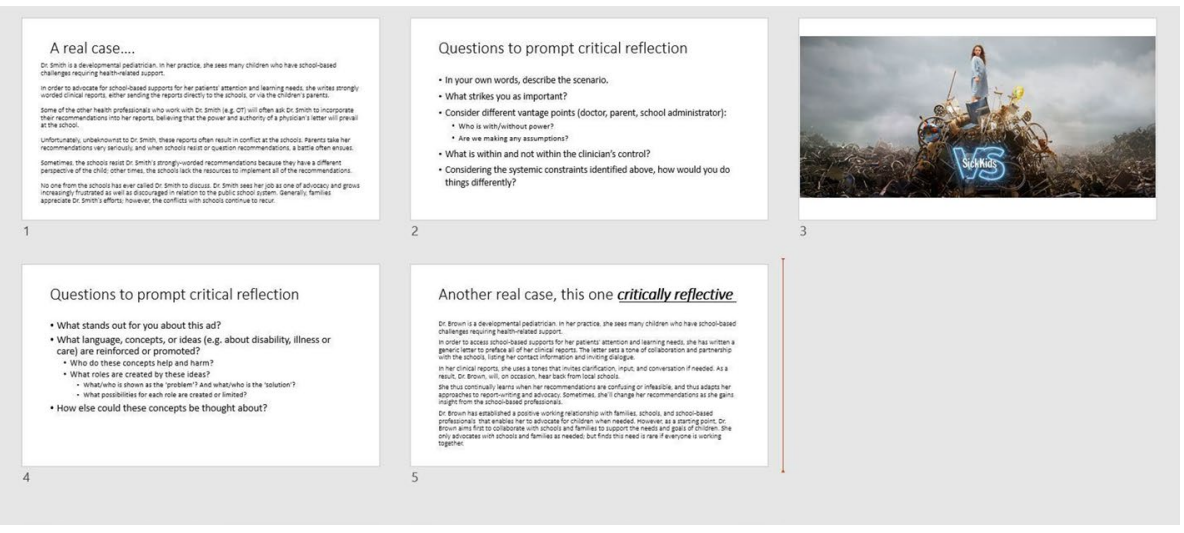




\section{Appendix 3: Debriefing Script}

\section{Debriefing Script*}

\section{Setting the scene}

I'll spend about 15-20 minutes debriefing the case with you. First, l'll be interested to hear how you are feeling now that that case is over; second, l'd like someone to describe what the case was about to make sure we are all on the same page. Then, we'll explore particular elements of the case relating to the home and care situation. I'll be keen to hear what was going through your mind at various points in time. We'll end by summarizing some take-home points and how to apply them in your clinical practice.

\section{Reaction}

How are you feeling?

Potential follow-up question:

Other reactions? or 'How are the rest of you feeling?

\section{Description}

Can someone summarize the case from a medical point of view so that we are all on the same page?

Potential follow up questions:

What things did you think the patient needed?

\section{Analysis}

Signal the transition to the analysis of the case and frame the discussion:

I would like to spend a few minutes talking about the older adult's living and care situation.

Probes:

What, if anything, was noteworthy to you, about this older adult's living situation?

What impacts might the overall situation have on your practice as a care provider?

What were your thoughts about the PSW?

What were your thoughts about the family caregiver?

Are there any outstanding issues before we start to close?

\section{Application/summary}

I'd like to close the debriefing by having each you state one to two take-aways that will help you in the future. 


\section{Appendix 4: Codebook for "what" codes}

\begin{tabular}{|c|c|c|}
\hline Code & Subcodes & Description \\
\hline $\begin{array}{l}\text { Building on prior knowledge- } \\
\text { problem solving-integration }\end{array}$ & & $\begin{array}{l}\text { Integrating personal experience/ } \\
\text { knowledge-Integrating past } \\
\text { experience/knowledge-Integrat- } \\
\text { ing formal curricular experience/ } \\
\text { knowledge }\end{array}$ \\
\hline
\end{tabular}

Caregiver
Caregiver Competence
Knowledge, capacity to care
Caregiver Condition
e.g. Physical or emotional state, burnout, health
Caregiver needsrecommendations
e.g. Additional support-various explanations as to why, physical mobility

Safety concerns

Patient

Cognitive State-Memory loss

Emotional state-Mental health

Patient Behaviour

Safety concerns

Signs, symptoms, medication

Patient needs

Patient psycho-social factors

Social Determinants of Health consistent with CNA SDoH curriculum used in study

Access to education

Access to healthy food

Access to Housing
A good education \& culturally appropriate school environment leads to better health. Cost is a significant barrier to continuing education after high school

Eating poorly can have a number of negative health effects (e.g. increased food allergies, diabetes, hypertension). Household food insecurity is linked to poor general health (e.g. chronic conditions, depression). Food security appears to be on the rise in Canada with increased food bank use

Good housing (stable \& safe) $>$ better health. Poor housing (e.g. heating deficiency, overcrowding, vermin) > worsening health. Home inadequacies may increase exposure to lead, poor heating, etc. Homelessness is the most severe form of housing insecurity. Homelessness has the greatest impacts, including early death 


\begin{tabular}{|c|c|c|}
\hline Code & Subcodes & Description \\
\hline & Built and natural environment & $\begin{array}{l}\text { Where you live can affect your } \\
\text { health. Rural living can mean less } \\
\text { pollution-but also less access to } \\
\text { health-care services. Urban living } \\
\text { can mean better access to ser- } \\
\text { vices-but greater exposure to } \\
\text { pollution }\end{array}$ \\
\hline & Conditions of early childhood & $\begin{array}{l}\text { Critical stages of physical, mental, } \\
\text { and emotional development. Fun- } \\
\text { damental in creating a healthy } \\
\text { foundation for adult health. Keys } \\
\text { to positive long-term effects: } \\
\text { Health attachments, stimula- } \\
\text { tion, access to quality child care, } \\
\text { access to activities (e.g. dance) }\end{array}$ \\
\hline & $\begin{array}{l}\text { Employment and working condi- } \\
\text { tions }\end{array}$ & $\begin{array}{l}\text { A stressful job can contribute } \\
\text { to other physical \& psycho- } \\
\text { logical problems. Stress may be } \\
\text { increased by SDoH such as lower } \\
\text { incomes \& less education. BUT } \\
\text { good workplace conditions sup- } \\
\text { port well-being }\end{array}$ \\
\hline & Income & $\begin{array}{l}\text { Individuals, families, and com- } \\
\text { munities need sufficient income. } \\
\text { Poorer people experience more } \\
\text { illness and shorter lives than the } \\
\text { rich }\end{array}$ \\
\hline & Social inclusion & $\begin{array}{l}\text { Ability to participate in social \& } \\
\text { cultural activities, including paid } \\
\text { work and civil affairs. Ability to } \\
\text { enjoy social goods such as health } \\
\text { care, education, and language } \\
\text { services. Exclusion commonly } \\
\text { experienced by vulnerable groups } \\
\text { (e.g. recent immigrants, elderly, } \\
\text { people with disabilities, LGBTQ, } \\
\text { Indigenous b/c more limited } \\
\text { access to resources). Unemploy- } \\
\text { ment among recent immigrants } \\
\text { twice that of Canadian-born } \\
\text { workers }\end{array}$ \\
\hline
\end{tabular}

CanMeds roles, per the Royal College of Physicians \& Surgeons of Canada

Advocacy

Collaboration
Respond to an individual patient's health needs by advocating with the patient within and beyond the clinical environment

1. Work effectively other colleagues in the health care professions 2. Work with other colleagues in the health care professions to promote understanding, manage differences, and resolve conflicts. 3 . Hand over the care of a patient to another health care professional to facilitate continuity of safe patient care 


\begin{tabular}{|c|c|c|}
\hline Code & Subcodes & Description \\
\hline & Communication & $\begin{array}{l}\text { 1. Establish professional therapeu- } \\
\text { tic relationships with patients and } \\
\text { their families }\end{array}$ \\
\hline
\end{tabular}

2. Elicit and synthesize accurate and relevant information, incorporating the perspectives of patients and their families. 3. Share health care information and plans with patients and their families 4. Engage

Medical expertise

Professionalism patients and their families in developing plans that reflect the patient's health care needs and goals 5. Document and share written and electronic information about the medical encounter to optimize clinical dec

1. Practise medicine within their defined scope of practice and expertise 2. Perform a patientcentred clinical assessment and establish a management plan 3 . Plan and perform procedures and therapies for the purpose of assessment and/or management 4. Establish plans for ongoing care and, when appropriate, timely consultation 5. Actively contribute, as an individual and as a member of a team providing care, to the continuous improvement of health care quality and patient safety

1. Demonstrate a commitment to patients by applying best practices and adhering to high ethical standards 2. Demonstrate a commitment to society by recognizing and responding to societal expectations in health care 3. Demonstrate a commitment to the profession by adhering to standards and participating in physician-led regulation 4. Demonstrate a commitment to physician health and well-being to foster optimal patient care

For PSWs, something like managing responsive behaviours would count as their expertise as this is a big focus for their work, whereas something like medical knowledge is actually not expected of them

Recommendations for practice 


\section{Appendix 5: Regression Summary Tables}

What-regression summary table

\begin{tabular}{|c|c|c|c|}
\hline Predictors & $\begin{array}{l}\text { Intercept-only model } \\
\text { Odds ratios ( } 89 \% \text { CI) }\end{array}$ & $\begin{array}{l}\text { Non-hierarchical model } \\
\text { Odds ratios }(89 \% \mathrm{CI})\end{array}$ & $\begin{array}{l}\text { Hierarchical model } \\
\text { Odds ratios }(89 \% \mathrm{CI})\end{array}$ \\
\hline $\begin{array}{l}\text { Building: Intercept (Control, } \\
\text { Instruction, Facilitator 1) }\end{array}$ & $3.06(1.99-4.61)$ & $10.24(7.23-14.76)$ & $7.67(1.95-18.89)$ \\
\hline $\begin{array}{l}\text { Caregiver: Intercept (Control, } \\
\text { Instruction, Facilitator 1) }\end{array}$ & $3.99(3.00-5.31)$ & $0.57(0.35-0.93)$ & $0.57(0.17-1.41)$ \\
\hline $\begin{array}{l}\text { Patient: Intercept (Control, } \\
\text { Instruction, Facilitator 1) }\end{array}$ & $11.97(9.22-15.41)$ & $1.26(0.81-1.97)$ & $0.88(0.16-2.38)$ \\
\hline $\begin{array}{l}\text { Patientpsych: Intercept (Control, } \\
\text { Instruction, Facilitator 1) }\end{array}$ & $1.60(1.14-2.18)$ & $0.51(0.29-0.89)$ & $0.42(0.13-1.05)$ \\
\hline $\begin{array}{l}\text { SDOH: Intercept (Control, } \\
\text { Instruction, Facilitator 1) }\end{array}$ & $2.21(1.43-3.39)$ & $12.96(9.08-18.54)$ & $10.75(3.04-26.13)$ \\
\hline $\begin{array}{l}\text { Canmeds: Intercept (Control, } \\
\text { Instruction, Facilitator 1) }\end{array}$ & $8.27(6.23-10.70)$ & $6.90(4.84-9.95)$ & $6.28(1.41-17.74)$ \\
\hline $\begin{array}{l}\text { Expertise: Intercept (Control, } \\
\text { Instruction, Facilitator 1) }\end{array}$ & $4.43(3.34-5.81)$ & $1.37(0.85-2.18)$ & $0.80(0.16-2.01)$ \\
\hline $\begin{array}{l}\text { Recommendations: Intercept } \\
\text { (Control, Instruction, Facilita- } \\
\text { tor 1) }\end{array}$ & $2.08(1.46-2.92)$ & $0.98(0.58-1.61)$ & $0.78(0.25-1.91)$ \\
\hline $\begin{array}{l}\text { Building by Condition (Interven- } \\
\text { tion) }\end{array}$ & & $0.26(0.17-0.38)$ & $0.49(0.18-1.92)$ \\
\hline $\begin{array}{l}\text { Building by Session Type (Initial, } \\
\text { Homecare) }\end{array}$ & & $0.07(0.03-0.16)$ & $0.07(0.03-0.16)$ \\
\hline $\begin{array}{l}\text { Building by Session Type (Initial, } \\
\text { Debrief) }\end{array}$ & & $0.11(0.06-0.18)$ & $0.09(0.05-0.15)$ \\
\hline $\begin{array}{l}\text { Building by Session Type } \\
\text { (Follow-up, Homecare) }\end{array}$ & & $0.10(0.04-0.22)$ & $0.10(0.04-0.23)$ \\
\hline $\begin{array}{l}\text { Building by Session Type } \\
\text { (Follow-up, Debrief) }\end{array}$ & & $0.37(0.21-0.65)$ & $0.33(0.18-0.60)$ \\
\hline Building by Facilitator (2) & & $3.65(2.46-5.42)$ & $2.57(1.31-4.87)$ \\
\hline $\begin{array}{l}\text { Building by Condition (Interven- } \\
\text { tion) by Session Type (Initial, } \\
\text { Homecare) }\end{array}$ & & $0.70(0.20-2.07)$ & $0.68(0.20-2.11)$ \\
\hline $\begin{array}{l}\text { Building by Condition (Interven- } \\
\text { tion) by Session Type (Initial, } \\
\text { Debrief) }\end{array}$ & & $0.86(0.49-1.51)$ & $0.90(0.50-1.61)$ \\
\hline $\begin{array}{l}\text { Building by Condition (Interven- } \\
\text { tion) by Session Type (Follow- } \\
\text { up, Homecare) }\end{array}$ & & $0.71(0.27-1.77)$ & $0.90(0.33-2.31)$ \\
\hline $\begin{array}{l}\text { Building by Condition (Interven- } \\
\text { tion) by Session Type (Follow- } \\
\text { up, Homecare) }\end{array}$ & & $1.81(0.90-3.58)$ & $1.72(0.85-3.45)$ \\
\hline $\begin{array}{l}\text { Building by Condition (Interven- } \\
\text { tion) by Session Type (Initial, } \\
\text { Homecare) by Facilitator (2) }\end{array}$ & & $0.90(0.33-2.44)$ & $0.76(0.28-2.14)$ \\
\hline
\end{tabular}




\begin{tabular}{|c|c|c|c|}
\hline Predictors & $\begin{array}{l}\text { Intercept-only model } \\
\text { Odds ratios ( } 89 \% \mathrm{CI})\end{array}$ & $\begin{array}{l}\text { Non-hierarchical model } \\
\text { Odds ratios }(89 \% \mathrm{CI})\end{array}$ & $\begin{array}{l}\text { Hierarchical model } \\
\text { Odds ratios }(89 \% \mathrm{CI})\end{array}$ \\
\hline $\begin{array}{l}\text { Building by Condition (Interven- } \\
\text { tion) by Session Type ((Initial, } \\
\text { Debrief) by Facilitator (2) }\end{array}$ & & $2.36(1.32-4.26)$ & $2.74(1.50-5.05)$ \\
\hline $\begin{array}{l}\text { Building by Condition (Interven- } \\
\text { tion) by Session Type (Follow- } \\
\text { up, Homecare) by Facilitator (2) }\end{array}$ & & $3.28(1.40-8.16)$ & $2.50(1.03-6.28)$ \\
\hline $\begin{array}{l}\text { Building by Condition (Interven- } \\
\text { tion) by Session Type (Follow- } \\
\text { up, Homecare) by Facilitator (2) }\end{array}$ & & $0.84(0.44-1.65)$ & $0.87(0.44-1.74)$ \\
\hline $\begin{array}{l}\text { Caregiver by Condition (Interven- } \\
\text { tion) }\end{array}$ & & $2.14(1.30-3.50)$ & $1.61(0.44-4.35)$ \\
\hline $\begin{array}{l}\text { Caregiver by Session Type (Initial, } \\
\text { Homecare) }\end{array}$ & & $11.59(6.20-22.19)$ & $10.66(5.58-20.37)$ \\
\hline $\begin{array}{l}\text { Caregiver by Session Type (Initial, } \\
\text { Debrief) }\end{array}$ & & $6.40(3.68-11.22)$ & $6.03(3.45-10.58)$ \\
\hline $\begin{array}{l}\text { Caregiver by Session Type } \\
\text { (Follow-up, Homecare) }\end{array}$ & & $8.40(4.20-16.68)$ & $7.68(3.88-15.36)$ \\
\hline $\begin{array}{l}\text { Caregiver by Session Type } \\
\text { (Follow-up, Debrief) }\end{array}$ & & $14.31(7.88-26.35)$ & $14.24(7.69-26.37)$ \\
\hline Caregiver by Facilitator (2) & & $3.45(2.11-5.70)$ & $2.99(1.60-5.44)$ \\
\hline $\begin{array}{l}\text { Caregiver by Condition (Interven- } \\
\text { tion) by Session Type (Initial, } \\
\text { Homecare) }\end{array}$ & & $0.32(0.16-0.65)$ & $0.34(0.17-0.71)$ \\
\hline $\begin{array}{l}\text { Caregiver by Condition (Interven- } \\
\text { tion) by Session Type ((Initial, } \\
\text { Debrief) }\end{array}$ & & $0.13(0.07-0.23)$ & $0.13(0.07-0.24)$ \\
\hline $\begin{array}{l}\text { Caregiver by Condition (Interven- } \\
\text { tion) by Session Type (Follow- } \\
\text { up, Homecare) }\end{array}$ & & $0.34(0.15-0.78)$ & $0.37(0.16-0.86)$ \\
\hline $\begin{array}{l}\text { Caregiver by Condition (Interven- } \\
\text { tion) by Session Type (Follow- } \\
\text { up, Homecare) }\end{array}$ & & $0.87(0.45-1.68)$ & $0.93(0.48-1.80)$ \\
\hline $\begin{array}{l}\text { Caregiver by Condition (Interven- } \\
\text { tion) by Session Type (Initial, } \\
\text { Homecare) by Facilitator (2) }\end{array}$ & & $0.53(0.26-1.08)$ & $0.60(0.29-1.24)$ \\
\hline $\begin{array}{l}\text { Caregiver by Condition (Interven- } \\
\text { tion) by Session Type (Initial, } \\
\text { Debrief) by Facilitator ( } 2 \text { ) }\end{array}$ & & $1.08(0.59-1.97)$ & $1.16(0.63-2.11)$ \\
\hline $\begin{array}{l}\text { Caregiver by Condition (Interven- } \\
\text { tion) by Session Type (Follow- } \\
\text { up, Homecare) by Facilitator ( } 2 \text { ) }\end{array}$ & & $0.15(0.06-0.35)$ & $0.17(0.07-0.41)$ \\
\hline $\begin{array}{l}\text { Caregiver by Condition (Interven- } \\
\text { tion) by Session Type (Follow- } \\
\text { up, Homecare) by Facilitator ( } 2 \text { ) }\end{array}$ & & $0.59(0.31-1.12)$ & $0.62(0.32-1.21)$ \\
\hline $\begin{array}{l}\text { Patient by Condition (Interven- } \\
\text { tion) }\end{array}$ & & $1.73(1.09-2.75)$ & $1.28(0.35-4.01)$ \\
\hline $\begin{array}{l}\text { Patient by Session Type (Initial, } \\
\text { Homecare) }\end{array}$ & & $32.12(18.27-56.11)$ & $30.77(17.51-55.17)$ \\
\hline
\end{tabular}




\begin{tabular}{|c|c|c|c|}
\hline Predictors & $\begin{array}{l}\text { Intercept-only model } \\
\text { Odds ratios }(89 \% \mathrm{CI})\end{array}$ & $\begin{array}{l}\text { Non-hierarchical model } \\
\text { Odds ratios }(89 \% \mathrm{CI})\end{array}$ & $\begin{array}{l}\text { Hierarchical model } \\
\text { Odds ratios }(89 \% \mathrm{CI})\end{array}$ \\
\hline $\begin{array}{l}\text { Patient by Session Type (Initial, } \\
\text { Debrief) }\end{array}$ & & $3.69(2.22-6.10)$ & $3.45(2.09-5.72)$ \\
\hline $\begin{array}{l}\text { Patient by Session Type (Follow- } \\
\text { up, Homecare) }\end{array}$ & & $21.74(12.22-39.21)$ & $21.47(12.05-39.08)$ \\
\hline $\begin{array}{l}\text { Patient by Session Type (Follow- } \\
\text { up, Debrief) }\end{array}$ & & $10.77(6.22-19.36)$ & $10.63(6.05-18.78)$ \\
\hline Patient by Facilitator (2) & & $2.44(1.55-3.83)$ & $2.21(1.27-3.78)$ \\
\hline $\begin{array}{l}\text { Patient by Condition (Interven- } \\
\text { tion) by Session Type (Initial, } \\
\text { Homecare) }\end{array}$ & & $0.55(0.30-1.02)$ & $0.58(0.31-1.10)$ \\
\hline $\begin{array}{l}\text { Patient by Condition (Interven- } \\
\text { tion) by Session Type ((Initial, } \\
\text { Debrief) }\end{array}$ & & $0.15(0.09-0.26)$ & $0.15(0.09-0.26)$ \\
\hline $\begin{array}{l}\text { Patient by Condition (Interven- } \\
\text { tion) by Session Type (Follow- } \\
\text { up, Homecare) }\end{array}$ & & $0.89(0.46-1.76)$ & $0.94(0.49-1.86)$ \\
\hline $\begin{array}{l}\text { Patient by Condition (Interven- } \\
\text { tion) by Session Type (Follow- } \\
\text { up, Homecare) }\end{array}$ & & $0.92(0.50-1.72)$ & $0.98(0.53-1.82)$ \\
\hline $\begin{array}{l}\text { Patient by Condition (Interven- } \\
\text { tion) by Session Type (Initial, } \\
\text { Homecare) by Facilitator (2) }\end{array}$ & & $0.63(0.34-1.18)$ & $0.68(0.36-1.30)$ \\
\hline $\begin{array}{l}\text { Patient by Condition (Interven- } \\
\text { tion) by Session Type ((Initial, } \\
\text { Debrief) by Facilitator (2) }\end{array}$ & & $2.31(1.33-4.04)$ & $2.46(1.39-4.29)$ \\
\hline $\begin{array}{l}\text { Patient by Condition (Interven- } \\
\text { tion) by Session Type (Follow- } \\
\text { up, Homecare) by Facilitator ( } 2 \text { ) }\end{array}$ & & $0.88(0.46-1.73)$ & $0.95(0.48-1.89)$ \\
\hline $\begin{array}{l}\text { Patient by Condition (Interven- } \\
\text { tion) by Session Type (Follow- } \\
\text { up, Homecare) by Facilitator ( } 2 \text { ) }\end{array}$ & & $1.03(0.56-1.92)$ & $1.11(0.59-2.09)$ \\
\hline $\begin{array}{l}\text { Patientpsych by Condition (Inter- } \\
\text { vention) }\end{array}$ & & $0.56(0.29-1.06)$ & $0.70(0.25-2.28)$ \\
\hline $\begin{array}{l}\text { Patientpsych by Session Type } \\
\text { (Initial, Homecare) }\end{array}$ & & $4.14(1.93-8.74)$ & $4.39(2.03-9.39)$ \\
\hline $\begin{array}{l}\text { Patientpsych by Session Type } \\
\text { (Initial, Debrief) }\end{array}$ & & $1.77(0.91-3.46)$ & $1.73(0.90-3.40)$ \\
\hline $\begin{array}{l}\text { Patientpsych by Session Type } \\
\text { (Followup, Homecare) }\end{array}$ & & $3.43(1.56-7.42)$ & $3.58(1.61-7.81)$ \\
\hline $\begin{array}{l}\text { Patientpsych by Session Type } \\
\text { (Followup, Debrief) }\end{array}$ & & $6.65(3.37-13.25)$ & $7.65(3.78-15.69)$ \\
\hline Patientpsych by Facilitator (2) & & $1.12(0.59-2.07)$ & $1.15(0.55-2.37)$ \\
\hline $\begin{array}{l}\text { Patientpsych by Condition } \\
\text { (Intervention) by Session Type } \\
\text { (Initial, Homecare) }\end{array}$ & & $2.41(1.03-5.77)$ & $2.38(1.01-5.72)$ \\
\hline $\begin{array}{l}\text { Patientpsych by Condition } \\
\text { (Intervention) by Session Type } \\
\text { ((Initial, Debrief) }\end{array}$ & & $0.91(0.44-1.92)$ & $0.93(0.44-2.01)$ \\
\hline $\begin{array}{l}\text { Patientpsych by Condition } \\
\text { (Intervention) by Session Type } \\
\text { (Follow-up, Homecare) }\end{array}$ & & $2.22(0.92-5.30)$ & $2.14(0.88-5.18)$ \\
\hline
\end{tabular}




\begin{tabular}{|c|c|c|c|}
\hline Predictors & $\begin{array}{l}\text { Intercept-only model } \\
\text { Odds ratios }(89 \% \mathrm{CI})\end{array}$ & $\begin{array}{l}\text { Non-hierarchical model } \\
\text { Odds ratios }(89 \% \mathrm{CI})\end{array}$ & $\begin{array}{l}\text { Hierarchical model } \\
\text { Odds ratios }(89 \% \mathrm{CI})\end{array}$ \\
\hline $\begin{array}{l}\text { Patientpsych by Condition } \\
\text { (Intervention) by Session Type } \\
\text { (Follow-up, Homecare) }\end{array}$ & & $1.59(0.71-3.54)$ & $1.51(0.67-3.44)$ \\
\hline $\begin{array}{l}\text { Patientpsych by Condition } \\
\text { (Intervention) by Session Type } \\
\text { (Initial, Homecare) by Facilita- } \\
\text { tor (2) }\end{array}$ & & $1.65(0.72-3.86)$ & $1.58(0.67-3.80)$ \\
\hline $\begin{array}{l}\text { Patientpsych by Condition } \\
\text { (Intervention) by Session Type } \\
\text { ((Initial, Debrief) by Facilita- } \\
\text { tor (2) }\end{array}$ & & $3.48(1.65-7.43)$ & $3.24(1.52-7.07)$ \\
\hline $\begin{array}{l}\text { Patientpsych by Condition } \\
\text { (Intervention) by Session Type } \\
\text { (Follow-up, Homecare) by } \\
\text { Facilitator (2) }\end{array}$ & & $3.66(1.51-8.80)$ & $3.85(1.58-9.57)$ \\
\hline $\begin{array}{l}\text { Patientpsych by Condition } \\
\text { (Intervention) by Session Type } \\
\text { (Follow-up, Homecare) by } \\
\text { Facilitator ( } 2 \text { ) }\end{array}$ & & $2.69(1.21-6.03)$ & $2.47(1.10-5.61)$ \\
\hline SDoH by Condition (Intervention) & & $0.22(0.15-0.33)$ & $0.40(0.15-1.80)$ \\
\hline $\begin{array}{l}\text { SDoH by Session Type (Initial, } \\
\text { Homecare) }\end{array}$ & & $0.08(0.04-0.18)$ & $0.08(0.03-0.18)$ \\
\hline $\begin{array}{l}\text { SDoH by Session Type (Initial, } \\
\text { Debrief) }\end{array}$ & & $0.05(0.03-0.09)$ & $0.04(0.02-0.08)$ \\
\hline $\begin{array}{l}\text { SDoH by Session Type (Follow- } \\
\text { up, Homecare) }\end{array}$ & & $0.05(0.02-0.12)$ & $0.05(0.02-0.12)$ \\
\hline $\begin{array}{l}\text { SDoH by Session Type (Follow- } \\
\text { up, Debrief) }\end{array}$ & & $0.06(0.03-0.13)$ & $0.06(0.02-0.12)$ \\
\hline SDoH by Facilitator (2) & & $1.95(1.32-2.92)$ & $1.78(0.95-3.21)$ \\
\hline $\begin{array}{l}\text { SDoH by Condition (Interven- } \\
\text { tion) by Session Type (Initial, } \\
\text { Homecare) }\end{array}$ & & $3.88(1.41-10.43)$ & $3.25(1.19-8.90)$ \\
\hline $\begin{array}{l}\text { SDoH by Condition (Interven- } \\
\text { tion) by Session Type ((Initial, } \\
\text { Debrief) }\end{array}$ & & $1.19(0.58-2.40)$ & $1.10(0.53-2.26)$ \\
\hline $\begin{array}{l}\text { SDoH by Condition (Intervention) } \\
\text { by Session Type (Follow-up, } \\
\text { Homecare) }\end{array}$ & & $0.68(0.16-2.65)$ & $0.65(0.15-2.48)$ \\
\hline $\begin{array}{l}\text { SDoH by Condition (Intervention) } \\
\text { by Session Type (Follow-up, } \\
\text { Homecare) }\end{array}$ & & $2.12(0.72-5.82)$ & $2.01(0.67-5.66)$ \\
\hline $\begin{array}{l}\text { SDoH by Condition (Intervention) } \\
\text { by Session Type (Initial, Home- } \\
\text { care) by Facilitator (2) }\end{array}$ & & $0.20(0.06-0.61)$ & $0.20(0.06-0.61)$ \\
\hline $\begin{array}{l}\text { SDoH by Condition (Interven- } \\
\text { tion) by Session Type ((Initial, } \\
\text { Debrief) by Facilitator (2) }\end{array}$ & & $1.49(0.72-3.03)$ & $1.50(0.71-3.11)$ \\
\hline $\begin{array}{l}\text { SDoH by Condition (Intervention) } \\
\text { by Session Type (Follow-up, } \\
\text { Homecare) by Facilitator (2) }\end{array}$ & & $0.39(0.11-1.32)$ & $0.34(0.09-1.14)$ \\
\hline
\end{tabular}




\begin{tabular}{|c|c|c|c|}
\hline Predictors & $\begin{array}{l}\text { Intercept-only model } \\
\text { Odds ratios }(89 \% \mathrm{CI})\end{array}$ & $\begin{array}{l}\text { Non-hierarchical model } \\
\text { Odds ratios }(89 \% \mathrm{CI})\end{array}$ & $\begin{array}{l}\text { Hierarchical model } \\
\text { Odds ratios }(89 \% \mathrm{CI})\end{array}$ \\
\hline $\begin{array}{l}\text { SDoH by Condition (Intervention) } \\
\text { by Session Type (Follow-up, } \\
\text { Homecare) by Facilitator (2) }\end{array}$ & & $0.69(0.25-1.84)$ & $0.67(0.25-1.79)$ \\
\hline $\begin{array}{l}\text { Canmeds by Condition (Interven- } \\
\text { tion) }\end{array}$ & & $4.31(2.95-6.26)$ & $1.99(0.40-6.43)$ \\
\hline $\begin{array}{l}\text { Canmeds by Session Type (Initial, } \\
\text { Homecare) }\end{array}$ & & $0.60(0.33-1.09)$ & $0.55(0.30-1.01)$ \\
\hline $\begin{array}{l}\text { Canmeds by Session Type (Initial, } \\
\text { Debrief) }\end{array}$ & & $0.32(0.20-0.51)$ & $0.30(0.19-0.48)$ \\
\hline $\begin{array}{l}\text { Canmeds by Session Type } \\
\text { (Follow-up, Homecare) }\end{array}$ & & $0.69(0.37-1.26)$ & $0.66(0.36-1.22)$ \\
\hline $\begin{array}{l}\text { Canmeds by Session Type } \\
\text { (Follow-up, Debrief) }\end{array}$ & & $1.59(0.97-2.67)$ & $1.45(0.86-2.46)$ \\
\hline Canmeds by Facilitator (2) & & $1.49(1.03-2.18)$ & $1.31(0.82-2.06)$ \\
\hline $\begin{array}{l}\text { Canmeds by Condition (Interven- } \\
\text { tion) by Session Type (Initial, } \\
\text { Homecare) }\end{array}$ & & $0.33(0.17-0.65)$ & $0.33(0.17-0.65)$ \\
\hline $\begin{array}{l}\text { Canmeds by Condition (Interven- } \\
\text { tion) by Session Type ((Initial, } \\
\text { Debrief) }\end{array}$ & & $0.09(0.05-0.14)$ & $0.08(0.05-0.14)$ \\
\hline $\begin{array}{l}\text { Canmeds by Condition (Interven- } \\
\text { tion) by Session Type (Follow- } \\
\text { up, Homecare) }\end{array}$ & & $0.27(0.13-0.55)$ & $0.25(0.12-0.51)$ \\
\hline $\begin{array}{l}\text { Canmeds by Condition (Interven- } \\
\text { tion) by Session Type (Follow- } \\
\text { up, Homecare) }\end{array}$ & & $0.19(0.11-0.35)$ & $0.19(0.11-0.35)$ \\
\hline $\begin{array}{l}\text { Canmeds by Condition (Interven- } \\
\text { tion) by Session Type (Initial, } \\
\text { Homecare) by Facilitator (2) }\end{array}$ & & $1.13(0.58-2.24)$ & $1.31(0.66-2.58)$ \\
\hline $\begin{array}{l}\text { Canmeds by Condition (Interven- } \\
\text { tion) by Session Type ((Initial, } \\
\text { Debrief) by Facilitator (2) }\end{array}$ & & $4.85(2.93-8.21)$ & $5.21(3.11-8.71)$ \\
\hline $\begin{array}{l}\text { Canmeds by Condition (Interven- } \\
\text { tion) by Session Type (Follow- } \\
\text { up, Homecare) by Facilitator (2) }\end{array}$ & & $1.41(0.72-2.88)$ & $1.68(0.82-3.48)$ \\
\hline $\begin{array}{l}\text { Canmeds by Condition (Interven- } \\
\text { tion) by Session Type (Follow- } \\
\text { up, Homecare) by Facilitator ( } 2 \text { ) }\end{array}$ & & $1.08(0.59-1.93)$ & $1.27(0.70-2.36)$ \\
\hline $\begin{array}{l}\text { Expertise by Condition (Interven- } \\
\text { tion) }\end{array}$ & & $0.29(0.16-0.51)$ & $0.48(0.17-2.01)$ \\
\hline $\begin{array}{l}\text { Expertise by Session Type (Initial, } \\
\text { Homecare) }\end{array}$ & & $5.22(2.81-9.84)$ & $5.64(3.00-10.62)$ \\
\hline $\begin{array}{l}\text { Expertise by Session Type (Initial, } \\
\text { Debrief) }\end{array}$ & & $1.68(0.97-2.92)$ & $1.76(1.01-3.10)$ \\
\hline $\begin{array}{l}\text { Expertise by Session Type } \\
\text { (Follow-up, Homecare) }\end{array}$ & & $8.56(4.60-15.89)$ & $9.02(4.90-17.04)$ \\
\hline $\begin{array}{l}\text { Expertise by Session Type } \\
\text { (Follow-up, Debrief) }\end{array}$ & & $4.53(2.51-8.37)$ & $5.05(2.76-9.33)$ \\
\hline Expertise by Facilitator (2) & & $0.82(0.46-1.45)$ & $0.91(0.48-1.70)$ \\
\hline
\end{tabular}




\begin{tabular}{|c|c|c|c|}
\hline Predictors & $\begin{array}{l}\text { Intercept-only model } \\
\text { Odds ratios }(89 \% \mathrm{CI})\end{array}$ & $\begin{array}{l}\text { Non-hierarchical model } \\
\text { Odds ratios }(89 \% \mathrm{CI})\end{array}$ & $\begin{array}{l}\text { Hierarchical model } \\
\text { Odds ratios }(89 \% \mathrm{CI})\end{array}$ \\
\hline $\begin{array}{l}\text { Expertise by Condition (Interven- } \\
\text { tion) by Session Type (Initial, } \\
\text { Homecare) }\end{array}$ & & $4.32(2.09-9.01)$ & $4.45(2.08-9.69)$ \\
\hline $\begin{array}{l}\text { Expertise by Condition (Interven- } \\
\text { tion) by Session Type ((Initial, } \\
\text { Debrief) }\end{array}$ & & $0.56(0.29-1.10)$ & $0.55(0.27-1.12)$ \\
\hline $\begin{array}{l}\text { Expertise by Condition (Interven- } \\
\text { tion) by Session Type (Follow- } \\
\text { up, Homecare) }\end{array}$ & & $4.02(1.87-8.76)$ & $4.08(1.87-9.05)$ \\
\hline $\begin{array}{l}\text { Expertise by Condition (Interven- } \\
\text { tion) by Session Type (Follow- } \\
\text { up, Homecare) }\end{array}$ & & $4.06(1.98-8.51)$ & $4.11(1.94-8.73)$ \\
\hline $\begin{array}{l}\text { Expertise by Condition (Interven- } \\
\text { tion) by Session Type (Initial, } \\
\text { Homecare) by Facilitator (2) }\end{array}$ & & $3.93(1.88-8.27)$ & $3.55(1.68-7.46)$ \\
\hline $\begin{array}{l}\text { Expertise by Condition (Interven- } \\
\text { tion) by Session Type ((Initial, } \\
\text { Debrief) by Facilitator (2) }\end{array}$ & & $8.70(4.36-17.12)$ & $7.79(3.93-15.38)$ \\
\hline $\begin{array}{l}\text { Expertise by Condition (Interven- } \\
\text { tion) by Session Type (Follow- } \\
\text { up, Homecare) by Facilitator (2) }\end{array}$ & & $2.40(1.13-5.10)$ & $2.28(1.07-4.99)$ \\
\hline $\begin{array}{l}\text { Expertise by Condition (Interven- } \\
\text { tion) by Session Type (Follow- } \\
\text { up, Homecare) by Facilitator (2) }\end{array}$ & & $4.12(2.02-8.54)$ & $3.68(1.79-7.72)$ \\
\hline $\begin{array}{l}\text { Recommendations by Condition } \\
\text { (Intervention) }\end{array}$ & & $0.45(0.26-0.76)$ & $0.61(0.23-2.08)$ \\
\hline $\begin{array}{l}\text { Recommendations by Session } \\
\text { Type (Initial, Homecare) }\end{array}$ & & $0.57(0.22-1.37)$ & $0.56(0.22-1.38)$ \\
\hline $\begin{array}{l}\text { Recommendations by Session } \\
\text { Type (Initial, Debrief) }\end{array}$ & & $2.15(1.20-3.85)$ & $2.22(1.25-3.95)$ \\
\hline $\begin{array}{l}\text { Recommendations by Session } \\
\text { Type (Follow-up, Homecare) }\end{array}$ & & $0.19(0.06-0.57)$ & $0.19(0.06-0.58)$ \\
\hline $\begin{array}{l}\text { Recommendations by Session } \\
\text { Type (Follow-up, Debrief) }\end{array}$ & & $2.40(1.25-4.60)$ & $2.58(1.32-5.07)$ \\
\hline $\begin{array}{l}\text { Recommendations by Facilita- } \\
\text { tor (2) }\end{array}$ & & $3.83(2.28-6.64)$ & $4.12(2.16-7.77)$ \\
\hline $\begin{array}{l}\text { Recommendations by Condition } \\
\text { (Intervention) by Session Type } \\
\text { (Initial, Homecare) }\end{array}$ & & $1.75(0.62-4.93)$ & $1.89(0.67-5.15)$ \\
\hline $\begin{array}{l}\text { Recommendations by Condition } \\
\text { (Intervention) by Session Type } \\
\text { ((Initial, Debrief) }\end{array}$ & & $0.71(0.38-1.33)$ & $0.73(0.39-1.39)$ \\
\hline $\begin{array}{l}\text { Recommendations by Condition } \\
\text { (Intervention) by Session Type } \\
\text { (Follow-up, Homecare) }\end{array}$ & & $0.68(0.16-2.74)$ & $0.69(0.16-2.74)$ \\
\hline $\begin{array}{l}\text { Recommendations by Condition } \\
\text { (Intervention) by Session Type } \\
\text { (Follow-up, Homecare) }\end{array}$ & & $5.55(2.72-11.49)$ & $5.97(2.98-12.14)$ \\
\hline $\begin{array}{l}\text { Recommendations by Condition } \\
\text { (Intervention) by Session Type } \\
\text { (Initial, Homecare) by Facilita- } \\
\text { tor (2) }\end{array}$ & & $0.62(0.22-1.69)$ & $0.59(0.21-1.62)$ \\
\hline
\end{tabular}




\begin{tabular}{|c|c|c|c|}
\hline Predictors & $\begin{array}{l}\text { Intercept-only model } \\
\text { Odds ratios }(89 \% \mathrm{CI})\end{array}$ & $\begin{array}{l}\text { Non-hierarchical model } \\
\text { Odds ratios }(89 \% \mathrm{CI})\end{array}$ & $\begin{array}{l}\text { Hierarchical model } \\
\text { Odds ratios }(89 \% \mathrm{CI})\end{array}$ \\
\hline $\begin{array}{l}\text { Recommendations by Condition } \\
\text { (Intervention) by Session Type } \\
\text { ((Initial, Debrief) by Facilita- } \\
\text { tor (2) }\end{array}$ & & $1.17(0.61-2.22)$ & $1.03(0.54-1.95)$ \\
\hline $\begin{array}{l}\text { Recommendations by Condition } \\
\text { (Intervention) by Session Type } \\
\text { (Follow-up, Homecare) by } \\
\text { Facilitator ( } 2 \text { ) }\end{array}$ & & $0.45(0.12-1.62)$ & $0.43(0.11-1.59)$ \\
\hline $\begin{array}{l}\text { Recommendations by Condition } \\
\text { (Intervention) by Session Type } \\
\text { (Follow-up, Homecare) by } \\
\text { Facilitator (2) }\end{array}$ & & $1.28(0.63-2.60)$ & $1.16(0.56-2.39)$ \\
\hline \multicolumn{4}{|l|}{ Random effects } \\
\hline$\sigma^{2}$ & -0.00 & & 0.00 \\
\hline$\tau 00$ & -0.01 & & -0.01 \\
\hline ICC & 0.03 & & -0.08 \\
\hline N & $16_{\text {Group }}$ & & $\begin{array}{l}16_{\text {Group }} \\
2 \text { Condition }\end{array}$ \\
\hline Observations & 3854 & 3854 & 3854 \\
\hline
\end{tabular}

How-regression summary table

\begin{tabular}{llll}
\hline Predictors & Intercept-only model & Non-hierarchical model & Hierarchical model \\
& Odds Ratios (89\% CI) & Odds Ratios (89\% CI) & Odds Ratios (89\% CI) \\
\hline
\end{tabular}

Intercept (Control, Instruction)

Condition (Intervention)

Session Type: Initial, Homecare

Session Type: Initial, Debrief

Session Type: Follow-up,

Homecare

Session Type: Follow-up,

Debrief

Facilitator (2)

Condition (Intervention) by Session Type (Initial, Homecare)

Condition (Intervention) by Session Type (Initial, Debrief)

Condition (Intervention) by Session Type (Follow-up, Homecare)

Condition (Intervention) by Session Type (Follow-up, Debrief)

Session Type (Initial, Homecare) by Facilitator (2)

Session Type (Initial, Debrief) by Facilitator (2)

Session Type (Follow-up, Homecare) by Facilitator (2)

$\begin{array}{lll}0.14(0.11-0.17) & 0.29(0.23-0.36) & 0.51(0.19-3.35) \\ 1.56(1.25-1.94) & 1.41(0.38-4.05) \\ 0.20(0.12-0.32) & 0.22(0.13-0.36) \\ 0.32(0.22-0.46) & 0.31(0.21-0.46) \\ 0.05(0.02-0.11) & 0.06(0.02-0.12) \\ & 0.23(0.14-0.36) & 0.23(0.14-0.38) \\ & 0.72(0.58-0.89) & 0.77(0.51-1.18) \\ 0.41(0.21-0.80) & 0.35(0.18-0.68) \\ & 1.39(0.95-2.04) & 1.39(0.93-2.05) \\ & 0.41(0.14-1.16) & 0.38(0.13-1.07) \\ & \\ 0.93(0.57-1.50) & 0.89(0.54-1.47) \\ & 0.72(0.36-1.38) & 0.65(0.33-1.25) \\ & & \\ & & \\ & & \\ & & \\ & & \\ & & \\ & & \\ & & \end{array}$




\begin{tabular}{llll}
\hline Predictors & $\begin{array}{l}\text { Intercept-only model } \\
\text { Odds Ratios }(89 \% \mathrm{CI})\end{array}$ & $\begin{array}{l}\text { Non-hierarchical model } \\
\text { Odds Ratios }(89 \% \mathrm{CI})\end{array}$ & $\begin{array}{l}\text { Hierarchical model } \\
\text { Odds Ratios }(89 \% \mathrm{CI})\end{array}$ \\
\hline $\begin{array}{l}\text { Session Type (Follow-up, } \\
\text { Debrief) by Facilitator (2) }\end{array}$ & & $1.23(0.76-1.99)$ & $1.25(0.76-2.03)$ \\
$\begin{array}{l}\text { Random effects } \\
\sigma^{2}\end{array}$ & 0.00 & & \\
$\tau 00$ & 0.10 & & -0.04 \\
$\mathrm{ICC}$ & 0.04 & & 0.15 \\
$\mathrm{~N}$ & $16_{\text {Group }}$ & & -0.40 \\
& & & 16 Group \\
Observations & 3854 & 3854 & 2 Condition \\
Marginal R ${ }^{2}$ / Conditional $\mathrm{R}^{2}$ & $0.000 / 0.021$ & 0.091 & 3854 \\
\hline
\end{tabular}

Acknowledgements We would like to thank Allia Karim and Nida Shahid for their roles in facilitation; Sabrina Teles and Paula Veinot for their roles in study coordination; and Lori Nemoy for supporting data analysis. We also thank Lindsay Baker and Maria Mylopoulos for their input into study design and framing. Finally, we thank Brett Diaz for his thorough review of this manuscript.

Funding This study was supported by the Arrell Family Chair in Health Professions Teaching, the Ontario Early Researcher Award, and an internal grant from the Centre for Ambulatory Care Education, Women's College Hospital.

\section{Declarations}

Ethical approval This study was approved by the institutional review board at the University of Toronto.

Open Access This article is licensed under a Creative Commons Attribution 4.0 International License, which permits use, sharing, adaptation, distribution and reproduction in any medium or format, as long as you give appropriate credit to the original author(s) and the source, provide a link to the Creative Commons licence, and indicate if changes were made. The images or other third party material in this article are included in the article's Creative Commons licence, unless indicated otherwise in a credit line to the material. If material is not included in the article's Creative Commons licence and your intended use is not permitted by statutory regulation or exceeds the permitted use, you will need to obtain permission directly from the copyright holder. To view a copy of this licence, visit http://creativecommons.org/licenses/by/4.0/.

\section{References}

Baker, L. R., Martimianakis, M. A., Nasirzadeh, Y., Northup, E., Gold, K., Friesen, F., et al. (2018). Compassionate care in the age of evidence-based practice: A critical discourse analysis in the context of chronic pain care. Academic Medicine, 93, 1841-1849.

Baker, L., Wright, S., Mylopoulos, M., Kulasegaram, K., \& Ng, S. (2020). Aligning and applying the paradigms and practices of education. Academic Medicine. https://doi.org/10.1097/ACM.0000000000 002693

Baker, L., Kangasjarv, E., McNeil, B., Houston, P., Mooney, S., \& Ng, S. (2019). "Disadvantaged patient populations": A theory-informed education needs assessment in an urban teaching hospital. Canadian Medical Education Journal, 10(4), 21.

Brookfield, S. D. (2000). The concept of critically reflective practice. In A. L. Wilson \& E. R. Hayes (Eds.), Handbook of adult and continuing education (New Editio., pp. 33-50). San Francisco, CA: Jossey-Bass.

Burkner, P. (2018). Advanced Bayesian multilevel modelling with the $\mathrm{R}$ package brms. The R Journal, 10(1), 395-411. https://doi.org/10.32614/RJ-2018-017

Burkner, P.-C. (2017). brms: An R package for Bayesian multilevel models using STan. Journal of Statistical Software, 80(1), 1-28. https://doi.org/10.18637/jss.v080.i01 
Carpenter, B., Gelman, A., Hoffman, M. D., Lee, D., Goodrich, B., Betancourt, M., et al. (2017). Stan: A probabilistic programming language. Journal of Statistical Software. https://doi.org/10.18637/jss.v076.i01

Charise, A. (2017). Site, sector, scope: Mapping the epistemological landscape of health humanities. The Journal of Medical Humanities, 38, 431-444. https://doi.org/10.1007/s10912-017-9445-5

Cheng, A., LaDonna, K., Cristancho, S., \& Ng, S. (2017). Navigating difficult conversations: The role of self-monitoring and reflection-in-action. Medical Education. https://doi.org/10.1111/medu.13448

Creswell, J. W. (2003). Research Design: Qualitative, Quantitative, and Mixed Methods Approaches. SAGE. http://books.google.ca/books/about/Research_Design.html?id=nSVxmN2KWeYC\&pgis=1. Accessed 18 Jan 2014

de la Croix, A., \& Veen, M. (2018). The reflective zombie: Problematizing the conceptual framework of reflection in medical education. Perspectives on Medical Education, 7(6), 394-400. https://doi.org/10. 1007/s40037-018-0479-9

Dewey, J. (1910). How We Think. Dover Publications Inc.

Diachun, L., Charise, A., Goldszmidt, M., Hui, Y., \& Lingard, L. (2014). Exploring the realities of curriculum-by-random-opportunity: The case of geriatrics on the internal medicine clerkship rotation. Canadian Geriatrics Journal, 17(4), 126.

Driessen, E. W., van Tartwijk, J., Overeem, K., Vermunt, J. D., \& van der Vleuten, C. P. M. (2005). Conditions for successful reflective use of portfolios in undergraduate medical education. Medical Education, 39(12), 1230-1235. https://doi.org/10.1111/j.1365-2929.2005.02337.x

Dyne, P. L., Strauss, R. W., \& Rinnert, S. (2002). Systems-based practice: The sixth core competency. Academic Emergency Medicine, 9(11), 1270-7.

Eppich, W., \& Cheng, A. (2015). Promoting excellence and reflective learning in simulation (PEARLS). Simulation in Healthcare: The Journal of the Society for Simulation in Healthcare, 10(2), 106-115. https://doi.org/10.1097/SIH.0000000000000072

Frank, J. R., \& Danoff, D. (2007). The CanMEDS initiative : Implementing an outcomes-based framework of physician competencies. Medical Teacher, 7, 642-647. https://doi.org/10.1080/01421590701746983

Freire, P. (2000). Pedagogy of the oppressed, 30th anniversary edition. New York: Continuum.

Greene, M. (1986). In search of a critical pedagogy. Harvard Educational Review, 56(4), 427-442. https:// doi.org/10.17763/haer.56.4.0107561h36u16213

Grierson, L., Winemaker, S., Taniguchi, A., Howard, M., Marshall, D., \& Zazulak, J. (2020). The reliability characteristics of the REFLECT rubric for assessing reflective capacity through expressive writing assignments: A replication study. Perspectives on Medical Education, 9(5), 281-285. https://doi.org/ 10.1007/s40037-020-00611-2

Habermas, J. (1971). Knowledge and human interests: A general perspective. Beacon Press.

Halman, M., Baker, L., \& Ng, S. (2017). Using critical consciousness to inform health professions education. Perspectives on Medical Education, 6(1), 12-20. https://doi.org/10.1007/s40037-016-0324-y

Hodges, B. D. (2015). Sea monsters and whirlpools: Navigating between examination and reflection in medical education. Medical Teacher, 37(3), 261-266. https://doi.org/10.3109/0142159X.2014.993601

Hooks, bell. (1994). Teaching to transgress : Education as the practice of freedom. https://books.google.ca/ books/about/Teaching_to_Transgress.html?id=_8bBQgAACAAJ. Accessed 17 May 2020

Hooks, bell. (2015). Talking back: Thinking feminist, thinking Black (2nd ed.). New York: Routledge. https://www.routledge.com/Talking-Back-Thinking-Feminist-Thinking-Black-2nd-Edition/hooks/p/ book/9781138821736. Accessed 9 March 2018

Kalet, A., Buckvar-Keltz, L., Monson, V., Harnik, V., Hubbard, S., Crowe, R., et al. (2018). Professional identity formation in medical school: One measure reflects changes during pre-clerkship training. MedEdPublish, 7(1). https://doi.org/10.15694/mep.2018.0000041.1

Kemmis, S. (2005). Knowing practice: Searching for saliences. Pedagogy, Culture \& Society, 13(3), 391426. https://doi.org/10.1080/14681360500200235

Kinsella, E. A. (2006). Poetic resistance: Juxtaposing personal and professional discursive constructions in a practice context. Journal of the Canadian Association for Curriculum Studies, 4(1), 35-49.

Kinsella, E. A., Caty, M.-E., Ng, S. L., \& Jenkins, K. (2012). Reflective practice for allied health: Theory and applications. In L. English (Ed.), Adult education and health (pp. 210-228). University of Toronto Press. Accessed 5 May 2013

Koole, S., Dornan, T., Aper, L., Scherpbier, A., Valcke, M., Cohen-Schotanus, J., \& Derese, A. (2011). Factors confounding the assessment of reflection: A critical review. BMC Medical Education, 11(1), 104. https://doi.org/10.1186/1472-6920-11-104

Kruschke, J. (2014). Doing bayesian data analysis: A tutorial with r, jags, and stan. Academic Press.

Kruschke, J. K., \& Liddell, T. M. (2018). The Bayesian new statistics: Hypothesis testing, estimation, metaanalysis, and power analysis from a Bayesian perspective. Psychonomic Bulletin and Review, 25(1), 178-206. https://doi.org/10.3758/s13423-016-1221-4 
Kumagai, A. K. (2014). From competencies to human interests: Ways of knowing and understanding in medical education. Academic Medicine, 89(7), 978-983. https://doi.org/10.1097/ACM.0000000000 000234

Kumagai, A. K., \& Lypson, M. L. (2009). Beyond cultural competence: Critical consciousness, social justice, and multicultural education. Academic Medicine, 84(6), 782-787. https://doi.org/10.1097/ACM. 0b013e3181a42398

Kumagai, A., Murphy, E., \& Ross, P. (2009). Diabetes stories: Use of patient narratives of diabetes to teach patient-centered care. Advances in Medical Education and Practice, 14(3), 315-326.

Kuper, A., Veinot, P., Leavitt, J., Levitt, S., Li, A., Goguen, J., et al. (2017). Epistemology, culture, justice and power: Non-bioscientific knowledge for medical training. Medical Education, 51(2), 158-173. https://doi.org/10.1111/medu.13115

Makowski, D., Ben-Shachar, M. S., \& Lüdecke, D. (2019a). bayestestR: Describing effects and their uncertainty, existence and significance within the Bayesian framework. The Journal of Open Source Software, 4(40), 1541.

Makowski, D., Lüdecke, D., Ben-Shachar, M. S., Patil, I., Wilson, M. D., \& Wiernik, B. M. (2019b). Credible Intervals (CI). https://easystats.github.io/bayestestR/articles/credible_interval.html.

McElreath, R. (2014). Rethinking: Statistical rethinking book package. R Package Version 1.391.

McElreath, R. (2020). Statistical rethinking : A Bayesian course with examples in R and Stan. Chapman and Hall/CRC.

Metzl, J. M., \& Hansen, H. (2014). Social Science \& Medicine Structural competency : Theorizing a new medical engagement with stigma and inequality. Social Science \& Medicine, 103, 126-133. https://doi. org/10.1016/j.socscimed.2013.06.032

Moniz, T., Arntfield, S., Miller, K., Lingard, L., Watling, C., \& Regehr, G. (2015). Considerations in the use of reflective writing for student assessment: Issues of reliability and validity. Medical Education, 49(9), 901-908. https://doi.org/10.1111/medu.12771

Mykhalovskiy, E., \& Farrell, K. (2005). 'Nothing happens in medical school that prepares you for working with anyone who's different:' informal learning and socio-clinical knowledge amongst family physicians. In Research in the sociology of health care (pp. 159-181). https://doi.org/10.1016/S02754959(05)23008-9

Mylopoulos, M., \& Woods, N. (2014). Preparing medical students for future learning using basic science instruction. Medical education, 48(7), 667-673.

Nelson, S., \& Purkis, M. E. (2004). Mandatory reflection: The Canadian reconstitution of the competent nurse. Nursing Inquiry, 11, 247-257. https://doi.org/10.1111/j.1440-1800.2004.00233.x

$\mathrm{Ng}, \mathrm{S}$. L. (2012). Reflection and reflective practice: Creating knowledge through experience. Seminars in Hearing. https://doi.org/10.1055/s-0032-1311673

Ng, S. L., Kinsella, E. A., Friesen, F., \& Hodges, B. (2015a). Reclaiming a theoretical orientation to reflection in medical education research: A critical narrative review. Medical Education. https://doi.org/10. 1111/medu. 12680

Ng, S. L., Kangasjarvi, E., Lorello, G. R., Nemoy, L., \& Brydges, R. (2019). 'There shouldn't be anything wrong with not knowing': Epistemologies in simulation. Medical Education. https://doi.org/10.1111/ medu. 13928

Ng, S. L., Baker, L., \& Friesen, F. (2018). Teaching for transformation. An online supplement. www.teach ingfortransformation.com. Accessed 11 April 2019

Ng, S. L., Lingard, L., Hibbert, K., Regan, S., Phelan, S., Stooke, R., et al. (2015b). Supporting children with disabilities at school: Implications for the advocate role in professional practice and education. Disability and Rehabilitation, 37(24), 2282-2290. https://doi.org/10.3109/09638288.2015.1021021

Ng, S. L., Mylopoulos, M., Kangasjarvi, E., Boyd, V. A., Teles, S., Orsino, A., et al. (2020). Critically reflective practice and its sources: A qualitative exploration. Medical Education, 54(4), 312-319. https://doi.org/10.1111/medu.14032

Ng, S. L., Wright, S. R., \& Kuper, A. (2019b). The divergence and convergence of critical reflection and critical reflexivity. Academic Medicine, 94(8), 1122-1128. https://doi.org/10.1097/ACM.0000000000 002724

Ousager, J., \& Johannessen, H. (2010). Humanities in undergraduate medical education: A literature review. Academic Medicine, 85(6), 988-998. https://doi.org/10.1097/acm.0b013e3181dd226b

Phelan, S. K., \& Ng, S. L. (2015). A case review: Reframing school-based practices using a critical perspective. Physical and Occupational Therapy in Pediatrics. https://doi.org/10.3109/01942638.2014.978933

R Core Team. (2019). R: A language and environment for statistical computing. Vienna, Austria: R Foundation for Statistical Computing. https://www.r-project.org/ 
Rowland, P., \& Kuper, A. (2018). Beyond vulnerability: How the dual role of patient-health care provider can inform health professions education. Advances in Health Sciences Education, 23(1), 115-131. https://doi.org/10.1007/s10459-017-9777-y

Schön, D. A. (1983). The reflective practitioner: How professionals think in action. Basic Books.

Sharma, M., Pinto, A. D., \& Kumagai, A. K. (2018). Teaching the social determinants of health. Academic Medicine, 93(1), 25-30. https://doi.org/10.1097/ACM.0000000000001689

Sherbino, J., Frank, J. R., Flynn, L., \& Snell, L. (2011). "Intrinsic Roles" rather than "armour": Renaming the "non-medical expert roles" of the CanMEDS framework to match their intent. Advances in Health Sciences Education, 16(5), 695-697.

Stan Development Team. (2020). RStan: The R interface to Stan. Stan. http://mc-stan.org/

Sumsion, J., \& Fleet, A. (1996). Reflection: Can we assess it? Should we assess it? Assessment \& Evaluation in Higher Education, 21(2), 121-131.

Tavares, W., Kuper, A., Kulasegaram, K., \& Whitehead, C. (2020). The compatibility principle: On philosophies in the assessment of clinical competence. Advances in Health Sciences Education, 25(4), 1003-1018. https://doi.org/10.1007/s10459-019-09939-9

Thille, P., Gibson, B. E., Abrams, T., McAdam, L. C., Mistry, B., \& Setchell, J. (2018). Enhancing the human dimensions of children's neuromuscular care: Piloting a methodology for fostering team reflexivity. Advances in Health Sciences Education, 23, 1-23. https://doi.org/10.1007/s10459-018-9834-1

Vehtari, A., Gelman, A., \& Gabry, J. (2016). Practical Bayesian model evaluation using leave-one-out crossvalidation and WAIC. Statistics and Computing, 27(5), 1413-1432.

Verma, S., Flynn, L., \& Seguin, R. (2005). Faculty's and residents' perceptions of teaching and evaluating the role of health advocate: A study at one Canadian university. Academic Medicine, 80(1), 103-108.

Whitehead, C. R., Austin, Z., \& Hodges, B. D. (2011). Intentions versus unintended discursive consequences: Reflections upon Sherbino et al.'s commentary on "Flower Power." Advances in Health Sciences Education: Theory and Practice, 16(5), 699-701. https://doi.org/10.1007/s10459-011-9337-9

Whitehead, C., Selleger, V., van de Kreeke, J., \& Hodges, B. (2014). The "missing person" in roles-based competency models: A historical, cross-national, contrastive case study. Medical Education, 48(8), 785-795. https://doi.org/10.1111/medu.12482

Young, M., Varpio, L., Uijtdehaage, S., \& Paradis, E. (2020). The spectrum of inductive and deductive research approaches using quantitative and qualitative data. Academic Medicine, 95(7), 1122-1122. https://doi.org/10.1097/ACM.0000000000003101

Publisher's Note Springer Nature remains neutral with regard to jurisdictional claims in published maps and institutional affiliations.

\section{Authors and Affiliations}

\section{Stella L. Ng ${ }^{1,2,8}$ (D) Jeff Crukley ${ }^{2,3} \cdot$ Ryan Brydges $^{4,6,8} \cdot$ Victoria Boyd $^{5,8}$. Adam Gavarkovs $^{5,8} \cdot$ Emilia Kangasjarvi $^{6} \cdot$ Sarah Wright ${ }^{7,8}$. Kulamakan Kulasegaram ${ }^{7,8} \cdot$ Farah Friesen $^{1} \cdot$ Nicole N. Woods $s^{7,8}$}

1 University of Toronto Centre for Interprofessional Education at University Health Network, Toronto Western Hospital, 399 Bathurst St., Nassau Annex (Entrance), Toronto, ON M5T 2S8, Canada

2 Department of Speech-Language Pathology, University of Toronto, Toronto, ON, Canada

3 Data Science and Statistics, Toronto, ON, Canada

4 Department of Medicine, University of Toronto, Toronto, ON, Canada

5 Institute of Health Policy, Management \& Evaluation, Faculty of Medicine, University of Toronto, Toronto, ON, Canada

6 Education, Unity Health Toronto, Toronto, ON, Canada

7 Department of Family and Community Medicine and Wilson Centre, Faculty of Medicine, University of Toronto, Toronto, ON, Canada

8 Wilson Centre, University of Toronto, Toronto, ON, Canada 